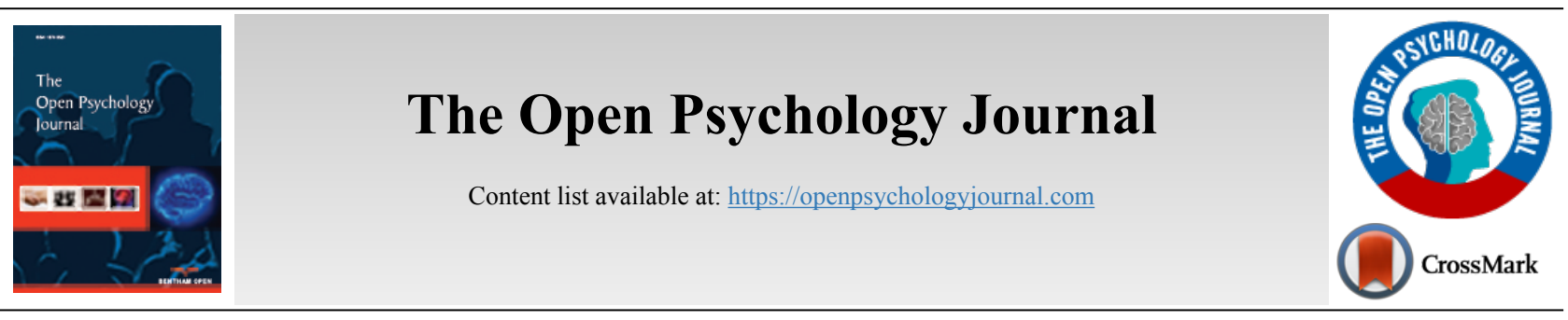

SYSTEMATIC REVIEW

\title{
Conceptualization, Tasks and Neurobiological Correlates of Self-Regulation in Children and Adolescents: A Systematic Review of the Literature (2015-2020)
}

\author{
Josefina Larraín-Valenzuela $^{1,2, *}$, Francisca Mardones ${ }^{3}$, Elisa Ansoleaga ${ }^{4}$ and Leonie Kausel ${ }^{2}$ \\ ${ }^{\prime}$ Psychology Doctoral Program, Faculty of Psychology, Universidad Diego Portales, Santiago, Chile \\ ${ }^{2}$ Center for Research in Social Complexity, Faculty of Government, Universidad del Desarrollo, Santiago, Chile \\ ${ }^{3}$ Psychology student, Faculty of Psychology, Universidad Diego Portales, Santiago, Chile \\ ${ }^{4}$ Faculty of Psychology, Universidad Diego Portales, Santiago, Chile
}

\begin{abstract}
:
Background:

Self-regulation is a complex capacity that favors the modification of behavior in accordance with environmental demands.

Objective:

This article aims to review the scientific literature that conceptualizes self-regulation, analyze its potential latent dimensions, identify the instruments used to measure this construct and the empirical findings associated with its neurobiological correlates.

Methods:

A systematic review of the scientific literature published between 2015 and 2020 . We include 29 empirical studies on children and adolescents self-regulatory capacity after combining the words self-regulation with cognition, brain and neurosciences.

Results:

Most of the articles included are from North America. A PICOS analysis was performed to increase understanding of self-regulatory capacity. Two dimensions of self-regulation are identified, contributing to a more global conceptualization of the concept of self-regulation; A cognitive dimension associated with executive functions, effortful control and inhibitory control, among others, and a dimension associated with personality, including traits such as irritability, impulsivity, openness and hyperactivity. Next, the instruments used to measure self-regulation are described, followed by a report of the important neurobiological findings, specifically, activation of the anterior cingulate cortex, dorsolateral prefrontal and ventromedial prefrontal cortex.

Conclusion:
\end{abstract}

Self-regulatory capacity is associated with a complex functioning that favors adaptive behavior and has neurobiological correlates.

Keywords: Systematic-review, Self-regulation behavior, Dimensions cognitive, Dimensions personality, Measure, Neurobiological.

\begin{tabular}{|l|l|l|l}
\hline Article History & Received: August 9, 2021 & Revised: October 21, 2021 & Accepted: November 17, 2021
\end{tabular}

\section{INTRODUCTION}

Self-regulation allows us to understand part of human behavior in the face of demanding environmental situations. Self-regulation allows the flexible adjustment of an adaptive response to the environment that underlies a supervisory system linked to executive attention [1]. Baumeister \& Heatherton (1996) state that self-regulation is the individual's

Address correspondence to this author at the, Doctoral Program, Faculty of Psychology, Universidad Diego Portales; Center for Research in Social Complexity, Faculty of Government, Universidad del Desarrollo, Santiago, Chile; Tel: +56999694736; E-mail: josefinalarrain@udd.cl ability to modify their behavior under the demands of specific situations [2]. Likewise, from a cognitive perspective, selfregulation refers to a cognitive capacity that involves attention processes and executive functions, which are sensitive to environmental influences in order to allow a better adaptation to the social environment [3].

Along the same line, self-regulation allows people to initiate, adjust, interrupt, stop, change and inhibit thoughts, feelings or actions in order to achieve personal goals or plans, or to maintain current behaviors [2]. In this way, the subject acts on the basis of more reflective than reactive action 
processes. Other authors allude to self-regulation as a process that regulates behavior, emotion, and cognition, and link this to activity in different brain regions [4]. A more restrictive way to analyze self-regulation would be with the capacity for selfcontrol, during which the subjects try to cancel out overpowering tendencies of an unwanted nature or impulses in a conscious and effortful way [5]. Self-control is considered a process, in which people would have resources to make their actions conscious, so it is usually linked to the will or control of the will. Specifically, it would be the ability to cancel or modify internal responses, behavioral tendencies (impulses), and refrain from acting on them voluntarily. Therefore, it demands a successful regulation of impulses [5]. One way to deepen the self-control process of impulsive behaviors is through the inhibition capacity, understood as part of executive functions.

Specifically, executive function is a cognitive construct used to describe goal-directed behaviors regulated mainly by the frontal lobes [6]. That is, executive functions are selfdirected actions that the individual uses to self-regulate, because it must interrupt a certain response that has generally been automated. This ability reflects a cognitive process that participates in the organization of goals. Within the selfregulatory capacity, effortful control is also mentioned as part of a top-down process that integrates cognitive (attention and inhibition) and behavioral mechanisms that contribute to regulation depending on the stage of development of each subject [7]. Also, it has been described as the relationship between the ability to focus attention and inhibit behavior in front of a certain task. These cognitive mechanisms show a partial overlap of their neural correlates because they are found within the network of the prefrontal cortex, and are part of the self-regulation processes [4, 7].

Regarding the inhibition mechanism, researchers such as Richard et al. (2017) describe that there are approaches associated with inhibition processes that break down the construct into a set of mechanisms that have functional properties and characteristics, supporting three types of inhibition [8]. First would be perceptual inhibition, which would be responsible for suppressing irrelevant stimuli from the environment; second, there would be cognitive inhibition, which would participate in the reduction of intrusive and irrelevant representations for the achievement of current goals; third, there would be behavioral inhibition, which would be responsible for suppressing arrogant and inappropriate responses or impulses in the context of the activity that is underway [9]. Also, this author proposes that inhibitory control involves one's own behavior and emotions. This definition can be limited with the inhibition of impulses, because it would act with other resources in a non-independent way and with more cognitive systems. In particular, inhibition participates in situations of conflict or interference, in which the responses are not pertinent to the objectives of the task; therefore, they must be suppressed or canceled for a better adaptation of the subject to the environment [9]. This creates an active inhibition against interference, allowing a successful self-regulation process [5].

Based on this background, there are different approaches to the conceptualization of the concept of self-regulation. While some authors place emphasis on the neurobiological study of the underlying cognitive processes of self-regulated behavior (they study specific components such as inhibitory control and/or effortful control); others pay attention to certain personality characteristics, more specifically aspects of temperament such as impulsivity, irritability, attention problems, etc. [4].

Traditionally, self-regulation has been associated with temperamental aspects of the human personality. Temperament is understood as a multifactorial construct (with biological and hereditary components) capable of being shaped through experience and by the confluence of biological and contextual variables, which underlie self-regulation processes [10, 11]. Temperament develops in childhood and is shaped by life experiences [4, 7]. Therefore, self-regulation is key to understanding development $[6,7]$. The development of early childhood self-regulation is often considered an early life marker for later successes [12]. Studies on self-regulation maintain that this capacity integrates prenatal, social and neurobiological mechanisms (endocrine, neuronal and genetic levels). Moreover, two specific and neurobiologically separable components are differentiated, which interact, such as: i) "topdown" (descending), reflecting the effortful and executive control processes dependent on the functioning of cortical structures such as the anterior cingulate cortex (AAC), ii) and a "bottom-up" way (ascending and / or reactive), reflecting more automatic (reactive) processes regulated by subcortical structures [4, 13].

More specifically, the top-down self-regulation process can be differentiated into two subcomponents, behavioral and emotional. The ascending self-regulation process would have components associated with inhibition, fear within behavior (over behavioral control) and impulsivity (under behavioral control). This model includes a neurobiological substrate that is associated both at a conceptual and behavioral level. This consensus is also evidenced at the neurobiological level, reporting that the dorsal AAC and dorsolateral prefrontal cortex (dIPFC) show greater activation compared to tasks of effortful control and executive attention $[14,15]$.

Some authors argue that little research has evaluated the development trajectory of self-regulation among children through a direct approach $[12,16]$. This study investigates the development of behavioral self-regulation to visualize patterns of development of self-regulatory capacity with the aim of generating support according to the needs of children and adolescents [12].

More empirical evidence is needed to provide a general perspective of self-regulatory capacity and its underlying dimensions [11, 17 - 19]. Given the complexity of the phenomenon, it is relevant to carry out a systematic review of the scientific literature, with the aim of identifying how selfregulation is conceptualized, as well as its underlying dimensions, the instruments that have been used for its evaluation and the main behavioral findings and possible brain regions involved. This is important in order to contribute to a comprehensive look at the construct of self-regulation during development. 
In this review, we include 29 articles that investigate selfcontrol in children or adolescents. The results section will detail the participants, the identification of self-regulation concepts and their dimensions, the instruments for their measurement, interventions, comparisons, behavioral and neurobiological results associated with the construct and the design of the study in order to understand the concept of selfregulation.

\section{MATERIALS AND METHODS}

This systematic review of the literature identifies, evaluates and combines knowledge from scientific studies regarding selfregulation $[20,21]$.

\subsection{Standards of Reporting}

The selection procedure of the articles followed the guidelines of the PRISMA method in order to ensure the quality of this work [21,22]. As proposed by the methodology of Guirao Goris (2015) for reviews, a systematic review of the literature published over the last 5 years (between 2015 and 2020) was carried out [23]. The protocol can be found on http://neurocics.udd.cl/data/Larrain-Valenzuela_et_al_2021_Pr otocolo_registro.pdf

\subsection{Identification of Publications}

The search for published studies was carried out using the PUBMED database (https://www.ncbi.nlm.nih.gov/) because it includes more than 32 million citations for biomedical literature from MEDLINE, life science journals, and online books. The search terms were "self-regulation", "cognition", "neuroscience" and "brain". These words were chosen with the aim of addressing the different dimensions of the word selfregulation as a psychological construct and as a whole, they were chosen to delimit the construct of this mental capacity and the neurobiological findings associated with it. Because the individual words were broad, the following combinations of words were used in the PUBMED database search for Title/Abstract: "self-regulation AND cognition", "selfregulation AND neuroscience" and "self-regulation AND brain". Words that were possibly linked to self-regulation such as "self-control or inhibitory control or emotional regulation" were not used because we needed to identify the dimensions and conceptualizations in a broad way and, from there, understand their particularities. Only articles from 1 st of January of 2015 until the 31 st of december of 2020 were included.

\subsection{Study Selection by Inclusion and Exclusion Criteria}

The inclusion criteria were: a) Self-regulation as an object of study. b) Studies of a quantitative nature with the possibility of replicating the methods. c) Studies in humans with or without neuropsychiatric diagnosis. d) Only the age range of childhood and adolescence was accepted. Specifically, late adolescence up to the age of 21 [24]. Articles that presented results from infants and included an adult population as a control group within the experimental design were accepted. e) Only articles indexed in Web of Science or Scopus were included as a criterion of academic quality.

The exclusion criteria were: a) Systematic review articles and / or meta-analysis, b) Articles referring to self-regulation in terms of neuronal electrical activity (e.g., The concept used in the context of neurofeedback techniques). c) Articles that used emotion regulation, and not self-regulation of a higher order of complexity. d) Articles where the word self-regulation was only mentioned in the abstract and was not a variable within the article.

\subsection{Search Strategy}

(1) The search was conducted by two independent researchers following inclusion and exclusion criteria.

(2) Collection of articles: three hundred thirty-eight articles were retrieved from the PUBMED database according to our criteria for the years considered and word search.

(3) Elimination of repeated articles $(n=35)$.

(4) Elimination of reviews or meta-analysis $(n=113)$.

(5) Elimination because the age requirement was not met or the age of the sample was not specified. Furthermore, articles were excluded when self-regulation was not a variable within the study. Information extracted only by abstract (eliminated $n=146)$. Remaining articles $(n=44)$.

(6) Elimination of articles due to exclusion criteria when analyzing the study in greater depth, in which there were inconsistencies associated with the approach to the concept of self-regulation $(\mathrm{n}=15)$.

(7) Finally, 29 articles were selected for the extraction of information according to the previously established inclusion criteria.

To ensure a greater organization of the systematic review, a review matrix was created in an Excel spreadsheet. A different sheet was created for each of the steps in the article selection and data collection process of this review, which can be reviewed in the supplemental material. Fig. (1) shows the summary of the information acquisition process and Table $\mathbf{2}$ shows all the selected articles with their general identification for subsequent extraction linked to the analysis categories.

The selected articles were downloaded and stored digitally in PDF format. A database was built for the systematic analysis of each of the selected articles, establishing 18 categories of analysis. These were: year, journal, country of study, concept of self-regulation, dimensions of self-regulation, hypothesis, sample size, characteristics of the sample, inclusion and exclusion criteria, behavioral instruments, experimental task, use of therapeutic intervention programs and the main limitations of the study. Table $\mathbf{1}$ defines each of the categories of analysis. 


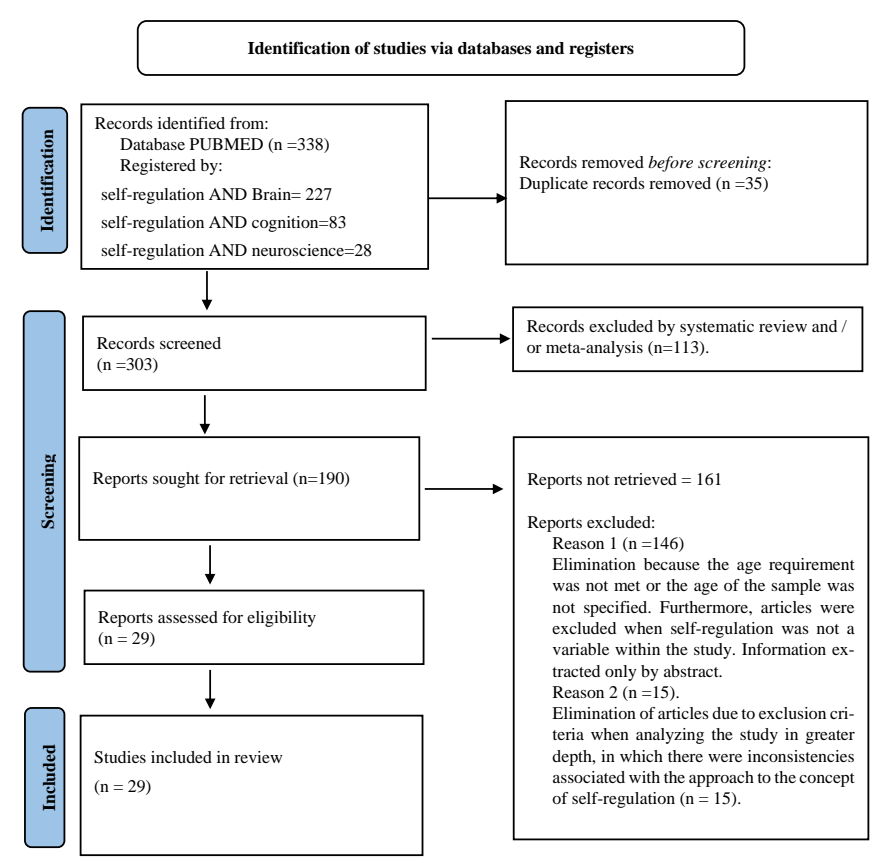

Fig. (1). PRISMA flow diagram of the articles included in this analysis. Source: Page MJ, McKenzie JE, Bossuyt PM, Boutron I, Hoffmann TC, Mulrow CD, et al. The PRISMA 2020 statement: an updated guideline for reporting systematic reviews. BMJ 2021;372:n71. doi: 10.1136/bmj.n71

Table 1. Categories of analysis and definitions.

\begin{tabular}{|c|c|}
\hline Analysis Category & Definition \\
\hline Year & Date of publication \\
\hline Magazine & Magazine of origin of the article publication \\
\hline Country of study & Sample country of origin \\
\hline Concept of self-regulation & Construction or idea on the main topic. The concept of self-regulation is implicit or explicit. \\
\hline Concepts associated with self-regulation & Ideas linked to self-regulation (eg. Mindfulness) \\
\hline Hypothesis / Objectives & Previous explanation that seeks to become a conclusion \\
\hline Sample number & Number of study population \\
\hline Characteristics of the sample & $\begin{array}{l}\text { Relevant aspects of the studied population } \\
\text { (age, sex, educational levels, exposed to stress, etc.) }\end{array}$ \\
\hline Exclusion and inclusion criteria & Sample recruitment criteria \\
\hline Behavioral Evaluation & Evaluation system applied to the sample \\
\hline Paradigm used Task used linked to the study technique & EEG, fMRI, TMS study techniques. \\
\hline Neurobiological results & Brain areas and oscillatory activity \\
\hline Behavioral results & Faced with the task, the responses of the directly observable subjects \\
\hline Second Results & Results that are associated with testing of the hypothesis \\
\hline Limitations & Components that could not be evaluated or tested \\
\hline Projections Possible & Study problems that arise after this study \\
\hline Other important & Aspects to consider not covered in previous items. \\
\hline
\end{tabular}

Table 2. Articles selected for this systematic review.

\begin{tabular}{|l|c|c|l|l|c|}
\hline \multicolumn{1}{|c|}{ Authors } & $\mathbf{N}$ & Year & \multicolumn{1}{|c|}{ Publication name } & \multicolumn{1}{|c|}{ Scientific journal } & Research country \\
\hline Anokhin et al. & {$[25]$} & 2017 & $\begin{array}{l}\text { Heritability of brain activity related to response inhibition: A } \\
\text { longitudinal genetic study in adolescent twins }\end{array}$ & $\begin{array}{l}\text { International Journal of } \\
\text { Psychophysiology }\end{array}$ & USA \\
\hline Bell et al. & {$[26]$} & 2019 & $\begin{array}{l}\text { The development of adaptive risk taking and the role of executive } \\
\text { functions in a large sample of school-age boys and girls }\end{array}$ & $\begin{array}{l}\text { Trends in Neuroscience and } \\
\text { Education }\end{array}$ & USA \\
\hline Bowling et al. & {$[27]$} & 2017 & $\begin{array}{l}\text { Cybercycling Effects on Classroom Behavior in Children with } \\
\text { Behavioral Health Disorders: An RCT }\end{array}$ & Pediatrics & USA \\
\hline
\end{tabular}




\begin{tabular}{|c|c|c|c|c|c|}
\hline Chavez et al. & [28] & 2020 & $\begin{array}{l}\text { A Parenting Program to Reduce Disruptive Behavior in Hispanic } \\
\text { Children with Acquired Brain Injury: A Randomized Controlled } \\
\text { Trial Conducted in Mexico }\end{array}$ & $\begin{array}{l}\text { Developmental } \\
\text { Neurorehabilitation }\end{array}$ & MÉXICO \\
\hline Authors & $\mathbf{N}$ & Year & \begin{tabular}{|l|} 
Publication name \\
\end{tabular} & Scientific journal & Research country \\
\hline Densing et al. & {$[29]$} & 2018 & $\begin{array}{l}\text { Effect of Stress Level on Different Forms of Self-Touch in Pre- } \\
\text { and Postadlescent Girls }\end{array}$ & Journal of Motor Behavior & GERMANY \\
\hline Edginton et al. & {$[30]$} & 2016 & $\begin{array}{l}\text { The design and implementation of a CBT-based intervention for } \\
\text { sensory processing difficulties in adolescents on the autism } \\
\text { spectrum }\end{array}$ & $\begin{array}{l}\text { Research in Developmental } \\
\text { Disabilities }\end{array}$ & ENGLAND \\
\hline Fosco et al. & {$[31]$} & 2018 & $\begin{array}{l}\text { Parent and child neurocognitive functioning predict response to } \\
\text { behavioral parent training for youth with ADHD }\end{array}$ & $\begin{array}{l}\text { ADHD Attention Deficit and } \\
\text { Hyperactivity Disorders }\end{array}$ & USA \\
\hline Gabriels et al. & {$[32]$} & 2015 & $\begin{array}{l}\text { Randomized Controlled Trial of Therapeutic Horseback Riding in } \\
\text { Children and Adolescents with Autism Spectrum Disorder }\end{array}$ & $\begin{array}{l}\text { Journal of the American } \\
\text { Academy of Child \& } \\
\text { Adolescent Psychiatry }\end{array}$ & USA \\
\hline $\begin{array}{l}\text { Goldschmidt et } \\
\text { al. }\end{array}$ & {$[33]$} & 2018 & $\begin{array}{l}\text { A Pilot Study of Neural Correlates of Loss of Control Eating in } \\
\text { Children with Overweight/Obesity: Probing Intermittent Access } \\
\text { to Food as a Means of Eliciting Disinhibited Eating }\end{array}$ & $\begin{array}{l}\text { Journal of Pediatric } \\
\text { Psychology }\end{array}$ & USA \\
\hline Grabell et al. & {$[34]$} & 2017 & $\begin{array}{l}\text { Comparing Self-Regulation-Associated Event Related Potentials } \\
\text { in Preschool Children with and without High Levels of Disruptive } \\
\text { Behavior }\end{array}$ & $\begin{array}{l}\text { Journal of Abnormal Child } \\
\text { Psychology }\end{array}$ & USA \\
\hline Hanson et al. & {$[35]$} & 2019 & $\begin{array}{l}\text { A Family Focused Intervention Influences Hippocampal- } \\
\text { Prefrontal Connectivity Through Gains in Self-Regulation }\end{array}$ & Child Development & USA \\
\hline Kaldoja et al. & {$[36]$} & 2015 & $\begin{array}{l}\text { Does gender matter? Differences in social-emotional behavior } \\
\text { among infants and toddlers before and after mild traumatic brain } \\
\text { injury: a preliminary study }\end{array}$ & Journal of Child Neurology & ESTONIA \\
\hline Lackner et al. & {$[37]$} & 2018 & $\begin{array}{l}\text { Adverse childhood experiences are associated with self-regulation } \\
\text { and the magnitude of the error-related negativity difference }\end{array}$ & Biological Psychology & CANADA \\
\hline Lakes et al. & {$[38]$} & 2019 & $\begin{array}{l}\text { Beyond Broadway: Analysis of Qualitative Characteristics of and } \\
\text { Individual Responses to Creatively Able, a Music and Movement } \\
\text { Intervention for Children with Autism }\end{array}$ & $\begin{array}{l}\text { International Journal of } \\
\text { Environmental Research and } \\
\text { Public Health } \\
\end{array}$ & USA \\
\hline Lim et al. & {$[39]$} & 2016 & $\begin{array}{l}\text { The child brain computes and utilizes internalized maternal } \\
\text { choices }\end{array}$ & Nature Communications & USA \\
\hline Lopez et al. & [40] & 2017 & $\begin{array}{l}\text { A balance of activity in brain control and reward systems predicts } \\
\text { self-regulatory outcomes }\end{array}$ & $\begin{array}{l}\text { Social Cognitive and } \\
\text { Affective Neuroscience }\end{array}$ & USA \\
\hline Lopez et al. & {$[41]$} & 2016 & $\begin{array}{l}\text { Motivational and neural correlates of self-control of eating: A } \\
\text { combined neuroimaging and experience sampling study in dieting } \\
\text { female college students }\end{array}$ & Appetite & USA \\
\hline Malanchini et al. & {$[42]$} & 2019 & $\begin{array}{l}\text { "Same but different": Associations between multiple aspects of } \\
\text { self-regulation, cognition, and academic abilities }\end{array}$ & $\begin{array}{l}\text { Journal of Personality and } \\
\text { Social Psychology }\end{array}$ & USA \\
\hline Marsh et al. & {$[43]$} & 2015 & $\begin{array}{l}\text { Anatomical characteristics of the cerebral surface in bulimia } \\
\text { nervosa }\end{array}$ & Biological Psychiatry & USA \\
\hline Marusak et al. & {$[44]$} & 2018 & $\begin{array}{l}\text { What's parenting got to do with it: emotional autonomy and brain } \\
\text { and behavioral responses to emotional conflict in children and } \\
\text { adolescents }\end{array}$ & Developmental Science & USA \\
\hline Miller et al. & {$[45]$} & 2015 & $\begin{array}{l}\text { Toddler's self-regulation strategies in a challenge context are nap- } \\
\text { dependent }\end{array}$ & Journal of Sleep Research & USA \\
\hline Modi et al. & [46] & 2018 & $\begin{array}{l}\text { Pattern of executive functioning in adolescents with epilepsy: A } \\
\text { multimethod measurement approach }\end{array}$ & Epilepsy \& Behavior & USA \\
\hline Nash et al. & {$[47]$} & 2015 & $\begin{array}{l}\text { Improving executive functioning in children with fetal alcohol } \\
\text { spectrum disorder }\end{array}$ & Child Neuropsychology & CANADA \\
\hline O'Connor et al. & {$[48]$} & 2015 & $\begin{array}{l}\text { The Prospective Joint Effects of Self-Regulation and Impulsive } \\
\text { Processes on Early Adolescence Alcohol Use }\end{array}$ & $\begin{array}{l}\text { Journal of Studies on Alcohol } \\
\text { and Drugs }\end{array}$ & USA \\
\hline Rohr et al. & {$[49]$} & 2020 & $\begin{array}{l}\text { Building functional connectivity neuromarkers of behavioral self- } \\
\text { regulation across children with and without Autism Spectrum } \\
\text { Disorder }\end{array}$ & $\begin{array}{l}\text { Developmental Cognitive } \\
\text { Neuroscience }\end{array}$ & CANADA \\
\hline Ryan et al. & {$[50]$} & 2019 & $\begin{array}{l}\text { Unraveling the Association between Pediatric Traumatic Brain } \\
\text { Injury and Social Dysfunction: The Mediating Role of Self- } \\
\text { Regulation }\end{array}$ & Journal of Neurotrauma & AUSTRALIA \\
\hline Tiego et al. & [51] & 2020 & $\begin{array}{l}\text { Common mechanisms of executive attention underlie executive } \\
\text { function and effortful control in children }\end{array}$ & Developmental Science & AUSTRALIA \\
\hline Urben et al. & [52] & 2018 & $\begin{array}{l}\text { Faces presenting sadness enhance self-control abilities in gifted } \\
\text { adolescents }\end{array}$ & $\begin{array}{l}\text { British Journal of } \\
\text { Developmental Psychology }\end{array}$ & SWITZERLAND \\
\hline
\end{tabular}


(Table 2) contd.....

\begin{tabular}{|l|l|l|l|l|l|}
\hline Wang et al. & {$[53]$} & 2017 & $\begin{array}{l}\text { Delay discounting is associated with the fractional amplitude of } \\
\text { low-frequency fluctuations and resting-state functional } \\
\text { connectivity in late adolescence }\end{array}$ & Scientific Reports \\
\hline
\end{tabular}

\section{RESULTS}

The results of the systematic review were based on the analysis of the different categories. The first section refers to an evaluation of the general conditions of scientific production on self-regulation. The second section addresses a PICOS analysis and incorporates the classification of the sample based on clinical diagnosis. The third section presents potential dimensions of self-regulation and its most representative conceptualizations. The third section reports the instruments used to measure self-regulation. Moreover, the fifth section presents the neurobiological findings of different study techniques used in neurosciences.

\subsection{Evaluation of the Production of Scientific Literature Regarding Self-Regulation}

The productions of research in self-regulation presented 338 articles published in the last 5 years. An example was the combination of words "self-regulation [Title / Abstract] AND Brain [Title / Abstract]" which registered 228 articles compared to the combination of words self-regulation [Title / Abstract] AND cognition [Title / Abstract] which registered 83 articles. This could suggest that the concept of self-regulation is predominantly intertwined with a neurobiological substrate. However, the combination self-regulation [Title / Abstract] AND neuroscience [Title / Abstract] only yielded 29 articles. In relation to the analysis of the 29 articles selected for this review, a greater number of publications was detected during 2018. See Graph. 1 to see the annual distribution of the publication of the 29 selected articles during the last 5 years.

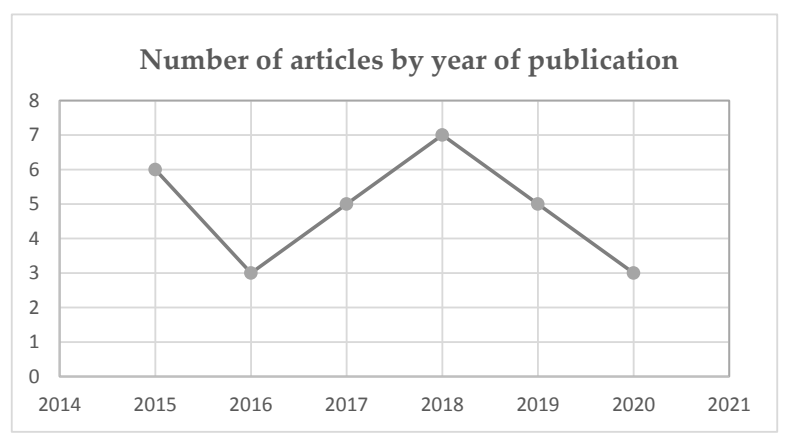

Graph. (1). Annual distribution of the 29 selected Publications.

When grouped by continent, the largest proportion of the reviewed research was from North America with 22 articles. Four studies were conducted in Europe, two in Oceania and one in Asia. The country with the highest number of publications included in this study was the United States with 18 articles. The specific age ranges of the participants were: Early childhood $10.3 \%$ ( 0 to 5 years), childhood $20.6 \%$ (6 to 11 years), adolescence $20.6 \%$ (12 to 18 years) and youth $6.8 \%$ (18 years or more). The remaining percentages were part of the articles with broader age ranges (e.g., articles [26, 27, 29, 32, $35,36,39,42,43,49,50,53])$.

\subsection{PICOS Analysis to Contribute to the Conceptualization of Self-Regulation}

For this section of the results, a descriptive Table $\mathbf{3}$ was prepared regarding the participants, interventions, comparisons, results and study designs (PICOS). Likewise, information was included on the classification of the articles with respect to the clinical diagnosis of the sample associated with typical or atypical development. Articles that explicitly presented the clinical diagnosis were considered within the atypical development category. Articles that presented a population at "risk" were incorporated in the typical development category.

There are only four articles that explicitly define the study sample as healthy (articles) [29, 45, 51, 53]. However, there are six other articles with difficulties in the inclusion and exclusion criteria. Given this, they were classified after reviewing the article in general, according to the variables they presented associated with health, cognitive and / or behavioral characteristics. Likewise, there are two articles that describe a population at "risk" with emphasis on the predisposition to suffer from physical and / or mental health problems. One article had a population associated with Early Adverse Experiences and the other article had a sample that presented a low socioeconomic level.

Also, obstacles to categorizing studies as being of typical development appeared because only four articles were explicit about the study population being healthy or having typical development. Eight articles are ambiguous regarding this classification. This allows hypothesizing possible predisposing factors that influence a broad spectrum of typical child development. Without a doubt, it reveals certain gray areas with respect to this concept of self-regulation. In none of the selected articles, the self-regulatory capacity appears as pathognomonic for the understanding of a certain neuropsychiatric difficulty, although it does influence the modulation of behavior sensitive to contextual changes.

The descriptive analysis PICOS detected therapeutic interventions in only seven articles, some of which involved children and others parents. Only seven articles carried out intervention designs with a small sample and with short intervention periods. There were no findings on prevention or promotion of self-regulation as a protective capacity in the field of mental health.

Another production condition was the variability of the sample within the atypical development. Article 12 was the only one that conducted research in infants with the aim of evaluating the development of self-regulatory capacity after moderate brain injury. This reveals a weakness associated with the complexity of the sample, and the increase in studies after 
24 months of age (e.g., article) [45]. Perhaps the studies of self-

regulation increase because it is understood as part of a maturation process, and that sometimes it can be altered.

Table 3. Descriptive analysis of PICOS and complementary information.

\begin{tabular}{|c|c|c|c|c|c|c|c|c|}
\hline Authors & Article & Participants & $\begin{array}{c}\text { Diagnostic } \\
\text { characteristics } \\
\text { of the sample }\end{array}$ & Intervention & Comparative & $\begin{array}{c}\text { Outcomes } \\
\text { Self-regulation } \\
\text { dimension } \\
\text { proposal }\end{array}$ & $\begin{array}{c}\text { Outcomes } \\
\text { Types } \\
\text { conceptualizations } \\
\text { of self-regulation }\end{array}$ & \begin{tabular}{|l|} 
Study Desing \\
\end{tabular} \\
\hline $\begin{array}{c}\text { Anokhin et } \\
\text { al. }\end{array}$ & {$[25]$} & $\begin{array}{c}\text { Adolescent and twins } \\
\text { assessed }\end{array}$ & $\begin{array}{c}\text { Typical } \\
\text { development }\end{array}$ & Not & Yes & $\begin{array}{c}\text { Self-regulation in } \\
\text { the cognitive } \\
\text { domain }\end{array}$ & $\begin{array}{l}\text { The article uses the } \\
\text { concept without } \\
\text { providing an explicit } \\
\text { or implicit definition }\end{array}$ & $\begin{array}{l}\text { Longitudinal } \\
\text { study }\end{array}$ \\
\hline Bell et al. & {$[26]$} & $\begin{array}{l}\text { School-age boys and } \\
\text { girls }\end{array}$ & $\begin{array}{c}\text { Typical } \\
\text { development }\end{array}$ & No & Yes & $\begin{array}{c}\text { Self-regulation in } \\
\text { the cognitive } \\
\text { domain }\end{array}$ & Explicit definition & $\begin{array}{c}\text { Experimental } \\
\text { study }\end{array}$ \\
\hline $\begin{array}{c}\text { Bowling et } \\
\text { al. }\end{array}$ & {$[27]$} & $\begin{array}{c}\text { Children With } \\
\text { Behavioral Health } \\
\text { Disorders }\end{array}$ & $\begin{array}{c}\text { Atypical } \\
\text { development }\end{array}$ & Yes & Yes & $\begin{array}{c}\text { Self-regulation in } \\
\text { the personality } \\
\text { domain }\end{array}$ & $\begin{array}{l}\text { The article uses the } \\
\text { concept without } \\
\text { providing an explicit } \\
\text { or implicit definition }\end{array}$ & $\begin{array}{c}\text { Experimental } \\
\text { study }\end{array}$ \\
\hline Chavez et al. & {$[28]$} & $\begin{array}{l}\text { Children with } \\
\text { Acquired Brain Injury }\end{array}$ & $\begin{array}{c}\text { Atypical } \\
\text { development }\end{array}$ & Yes & Yes & $\begin{array}{c}\text { Self-regulation in } \\
\text { the personality } \\
\text { domain }\end{array}$ & Explicit definition & $\begin{array}{c}\text { Experimental } \\
\text { study }\end{array}$ \\
\hline $\begin{array}{l}\text { Densing et } \\
\text { al. }\end{array}$ & [29] & $\begin{array}{c}\text { Pre- and } \\
\text { Postadolescent Girls }\end{array}$ & $\begin{array}{c}\text { Typical } \\
\text { development }\end{array}$ & Not & Yes & $\begin{array}{c}\text { Self-regulation in } \\
\text { the cognitive } \\
\text { domain }\end{array}$ & $\begin{array}{l}\text { The article uses the } \\
\text { concept without } \\
\text { providing an explicit } \\
\text { or implicit definition }\end{array}$ & $\begin{array}{c}\text { Experimental } \\
\text { study }\end{array}$ \\
\hline $\begin{array}{l}\text { Edginton et } \\
\text { al. }\end{array}$ & {$[30]$} & $\begin{array}{l}\text { Adolescents on the } \\
\text { autism spectrum }\end{array}$ & $\begin{array}{c}\text { Atypical } \\
\text { development }\end{array}$ & Yes & Yes & $\begin{array}{c}\text { Self-regulation in } \\
\text { the personality } \\
\text { domain }\end{array}$ & $\begin{array}{l}\text { The article uses the } \\
\text { concept without } \\
\text { providing an explicit } \\
\text { or implicit definition }\end{array}$ & $\begin{array}{c}\text { Experimental } \\
\text { study }\end{array}$ \\
\hline Fosco et al. & {$[31]$} & Youth with ADHD & $\begin{array}{c}\text { Atypical } \\
\text { development }\end{array}$ & Yes & Yes & $\begin{array}{c}\text { Self-regulation in } \\
\text { the cognitive } \\
\text { domain }\end{array}$ & $\begin{array}{c}\text { Implicit } \\
\text { conceptualization }\end{array}$ & $\begin{array}{c}\text { Experimental } \\
\text { study }\end{array}$ \\
\hline $\begin{array}{c}\text { Gabriels et } \\
\text { al. }\end{array}$ & {$[32]$} & $\begin{array}{c}\text { Children and } \\
\text { Adolescents with } \\
\text { Autism Spectrum } \\
\text { Disorder }\end{array}$ & $\begin{array}{c}\text { Atypical } \\
\text { development }\end{array}$ & Yes & Yes & $\begin{array}{c}\text { Self-regulation in } \\
\text { the personality } \\
\text { domain }\end{array}$ & $\begin{array}{l}\text { The article uses the } \\
\text { concept without } \\
\text { providing an explicit } \\
\text { or implicit definition }\end{array}$ & $\begin{array}{c}\text { Experimental } \\
\text { study }\end{array}$ \\
\hline $\begin{array}{l}\text { Goldschmidt } \\
\text { et al. }\end{array}$ & {$[33]$} & $\begin{array}{c}\text { Children With } \\
\text { Overweight/Obesity }\end{array}$ & $\begin{array}{c}\text { Atypical } \\
\text { development }\end{array}$ & Not & Yes & $\begin{array}{c}\text { Self-regulation in } \\
\text { the personality } \\
\text { domain }\end{array}$ & $\begin{array}{l}\text { The article uses the } \\
\text { concept without } \\
\text { providing an explicit } \\
\text { or implicit definition }\end{array}$ & $\begin{array}{c}\text { Experimental } \\
\text { study }\end{array}$ \\
\hline Grabell et al. & {$[34]$} & $\begin{array}{l}\text { Preschool Children } \\
\text { with and without } \\
\text { High Levels of } \\
\text { Disruptive Behavior }\end{array}$ & $\begin{array}{c}\text { Atypical } \\
\text { development }\end{array}$ & Not & Yes & $\begin{array}{c}\text { Self-regulation in } \\
\text { the cognitive } \\
\text { domain }\end{array}$ & $\begin{array}{c}\text { Implicit } \\
\text { conceptualization }\end{array}$ & $\begin{array}{c}\text { Experimental } \\
\text { study }\end{array}$ \\
\hline Hanson et al. & {$[35]$} & $\begin{array}{l}\text { African-American } \\
\text { children of low } \\
\text { socioeconomic status }\end{array}$ & $\begin{array}{c}\text { Typical } \\
\text { development }\end{array}$ & Yes & Yes & $\begin{array}{c}\text { Self-regulation in } \\
\text { the personality } \\
\text { domain }\end{array}$ & Explicit definition & $\begin{array}{l}\text { Longitudinal } \\
\text { study }\end{array}$ \\
\hline Kaldoja et al. & {$[36]$} & $\begin{array}{l}\text { Infants and toddlers } \\
\text { before and after mild } \\
\text { traumatic brain injury }\end{array}$ & $\begin{array}{c}\text { Atypical } \\
\text { development }\end{array}$ & Not & Yes & $\begin{array}{c}\text { Self-regulation in } \\
\text { the personality } \\
\text { domain }\end{array}$ & $\begin{array}{c}\text { Implicit } \\
\text { conceptualization }\end{array}$ & $\begin{array}{l}\text { Prospective } \\
\text { study }\end{array}$ \\
\hline $\begin{array}{l}\text { Lackner et } \\
\text { al. }\end{array}$ & {$[37]$} & $\begin{array}{l}\text { Adverse childhood } \\
\text { experiences }\end{array}$ & $\begin{array}{c}\text { Typical } \\
\text { development }\end{array}$ & Not & Yes & $\begin{array}{c}\text { Self-regulation in } \\
\text { the cognitive } \\
\text { domain }\end{array}$ & Explicit definition & $\begin{array}{c}\text { Experimental } \\
\text { study }\end{array}$ \\
\hline Lakes et al. & {$[38]$} & Children with Autism & $\begin{array}{c}\text { Atypical } \\
\text { development }\end{array}$ & Yes & Yes & $\begin{array}{c}\text { Self-regulation in } \\
\text { the personality } \\
\text { domain }\end{array}$ & $\begin{array}{l}\text { The article uses the } \\
\text { concept without } \\
\text { providing an explicit } \\
\text { or implicit definition }\end{array}$ & $\begin{array}{c}\text { Experimental } \\
\text { study }\end{array}$ \\
\hline Lim et al. & [39] & Heathy Children & $\begin{array}{c}\text { Typical } \\
\text { development }\end{array}$ & Not & Yes & $\begin{array}{c}\text { Self-regulation in } \\
\text { the personality } \\
\text { domain }\end{array}$ & $\begin{array}{c}\text { Implicit } \\
\text { conceptualization }\end{array}$ & $\begin{array}{c}\text { Experimental } \\
\text { study }\end{array}$ \\
\hline
\end{tabular}




\begin{tabular}{|c|c|c|c|c|c|c|c|c|}
\hline Lopez et al. & {$[40]$} & $\begin{array}{l}\text { Young women with a } \\
\text { history or history of } \\
\text { chronic dieting }\end{array}$ & $\begin{array}{c}\text { Atypical } \\
\text { development }\end{array}$ & Not & Yes & $\begin{array}{c}\text { Self-regulation in } \\
\text { the personality } \\
\text { domain }\end{array}$ & $\begin{array}{c}\text { Implicit } \\
\text { conceptualization }\end{array}$ & $\begin{array}{l}\text { Experimental } \\
\text { study }\end{array}$ \\
\hline Lopez et al. & [41] & $\begin{array}{l}\text { Young women with a } \\
\text { history or history of } \\
\text { chronic dieting }\end{array}$ & $\begin{array}{c}\text { Atypical } \\
\text { development }\end{array}$ & Not & Yes & $\begin{array}{c}\text { Self-regulation in } \\
\text { the personality } \\
\text { domain }\end{array}$ & $\begin{array}{c}\text { Implicit } \\
\text { conceptualization }\end{array}$ & $\begin{array}{l}\text { Experimental } \\
\text { study }\end{array}$ \\
\hline Authors & Article & Participants & $\begin{array}{c}\text { Diagnostic } \\
\text { characteristics } \\
\text { of the sample }\end{array}$ & Intervention & Comparative & $\begin{array}{c}\text { Outcomes } \\
\text { Self-regulation } \\
\text { dimension } \\
\text { proposal } \\
\end{array}$ & $\begin{array}{c}\text { Outcomes } \\
\text { Types } \\
\text { conceptualizations } \\
\text { of self-regulation } \\
\end{array}$ & Study Desing \\
\hline $\begin{array}{l}\text { Malanchini } \\
\text { et al. }\end{array}$ & {$[42]$} & $\begin{array}{l}\text { Children from third to } \\
\text { eighth grade }\end{array}$ & $\begin{array}{c}\text { Typical } \\
\text { development }\end{array}$ & Not & Yes & Both dimensions & Explicit definition & $\begin{array}{c}\text { Experimental } \\
\text { study }\end{array}$ \\
\hline Marsh et al. & {$[43]$} & $\begin{array}{l}\text { Adolescents and } \\
\text { adults with Bulimia } \\
\text { Nervosa }\end{array}$ & $\begin{array}{c}\text { Atypical } \\
\text { development }\end{array}$ & Not & Yes & $\begin{array}{c}\text { Self-regulation in } \\
\text { the cognitive } \\
\text { domain }\end{array}$ & $\begin{array}{l}\text { The article uses the } \\
\text { concept without } \\
\text { providing an explicit } \\
\text { or implicit definition }\end{array}$ & $\begin{array}{c}\text { Experimental } \\
\text { study }\end{array}$ \\
\hline $\begin{array}{c}\text { Marusak et } \\
\text { al. }\end{array}$ & {$[44]$} & $\begin{array}{c}\text { Children and } \\
\text { adolescents at risk for } \\
\text { mental health } \\
\text { problems }\end{array}$ & $\begin{array}{c}\text { Typical } \\
\text { development }\end{array}$ & Not & Yes & $\begin{array}{c}\text { Self-regulation in } \\
\text { the personality } \\
\text { domain }\end{array}$ & $\begin{array}{l}\text { The article uses the } \\
\text { concept without } \\
\text { providing an explicit } \\
\text { or implicit definition }\end{array}$ & $\begin{array}{c}\text { Experimental } \\
\text { study }\end{array}$ \\
\hline Miller et al. & {$[45]$} & Toddlers & $\begin{array}{c}\text { Typical } \\
\text { development }\end{array}$ & Not & Yes & $\begin{array}{c}\text { Self-regulation in } \\
\text { the personality } \\
\text { domain }\end{array}$ & Explicit definition & $\begin{array}{l}\text { Experimental } \\
\text { study }\end{array}$ \\
\hline Modi et al. & {$[46]$} & $\begin{array}{l}\text { Adolescents with } \\
\text { epilepsy }\end{array}$ & $\begin{array}{c}\text { Atypical } \\
\text { development }\end{array}$ & Not & Yes & $\begin{array}{c}\text { Self-regulation in } \\
\text { the cognitive } \\
\text { domain }\end{array}$ & $\begin{array}{c}\text { Implicit } \\
\text { conceptualization }\end{array}$ & $\begin{array}{l}\text { Experimental } \\
\text { study }\end{array}$ \\
\hline Nash et al. & {$[47]$} & $\begin{array}{l}\text { children with fetal } \\
\text { alcohol spectrum } \\
\text { disorders }\end{array}$ & $\begin{array}{c}\text { Atypical } \\
\text { development }\end{array}$ & Yes & Yes & Both dimensions & $\begin{array}{c}\text { Implicit } \\
\text { conceptualization }\end{array}$ & $\begin{array}{l}\text { Experimental } \\
\text { study }\end{array}$ \\
\hline $\begin{array}{c}\text { O'Connor et } \\
a l .\end{array}$ & {$[48]$} & $\begin{array}{l}\text { Children and } \\
\text { adolescents at risk of } \\
\text { alcohol consumption }\end{array}$ & $\begin{array}{c}\text { Typical } \\
\text { development }\end{array}$ & Not & Yes & $\begin{array}{c}\text { Self-regulation in } \\
\text { the personality } \\
\text { domain }\end{array}$ & $\begin{array}{c}\text { Implicit } \\
\text { conceptualization }\end{array}$ & $\begin{array}{l}\text { Longitudinal } \\
\text { study }\end{array}$ \\
\hline Rohr et al. & [49] & $\begin{array}{l}\text { Children with and } \\
\text { without autism } \\
\text { spectrum disorder }\end{array}$ & $\begin{array}{c}\text { Atypical } \\
\text { development }\end{array}$ & Not & Yes & $\begin{array}{c}\text { Self-regulation in } \\
\text { the cognitive } \\
\text { domain }\end{array}$ & $\begin{array}{c}\text { Implicit } \\
\text { conceptualization }\end{array}$ & $\begin{array}{l}\text { Experimental } \\
\text { study }\end{array}$ \\
\hline Ryan et al. & {$[50]$} & $\begin{array}{l}\text { Pediatric Traumatic } \\
\text { Brain Injury and } \\
\text { Social Dysfunction }\end{array}$ & $\begin{array}{c}\text { Atypical } \\
\text { development }\end{array}$ & Not & Yes & $\begin{array}{c}\text { Self-regulation in } \\
\text { the cognitive } \\
\text { domain }\end{array}$ & $\begin{array}{c}\text { Implicit } \\
\text { conceptualization }\end{array}$ & $\begin{array}{l}\text { Experimental } \\
\text { study }\end{array}$ \\
\hline Tiego et al. & {$[51]$} & Children & $\begin{array}{c}\text { Typical } \\
\text { development }\end{array}$ & Not & Yes & Both dimensions & Explicit definition & $\begin{array}{c}\text { Experimental } \\
\text { study }\end{array}$ \\
\hline Urben et al. & {$[52]$} & Gifted adolescents & $\begin{array}{c}\text { Atypical } \\
\text { development }\end{array}$ & Not & Yes & $\begin{array}{c}\text { Self-regulation in } \\
\text { the cognitive } \\
\text { domain }\end{array}$ & Explicit definition & $\begin{array}{l}\text { Experimental } \\
\text { study }\end{array}$ \\
\hline Wang et al. & {$[53]$} & Late adolescence & $\begin{array}{c}\text { Typical } \\
\text { development }\end{array}$ & Not & Yes & $\begin{array}{c}\text { Self-regulation in } \\
\text { the cognitive } \\
\text { domain }\end{array}$ & Explicit definition & $\begin{array}{l}\text { Experimental } \\
\text { study }\end{array}$ \\
\hline
\end{tabular}

With regard to developmental disorders, articles of children with a diagnosis of autism spectrum disorder appeared (e.g., articles [30, 32, 38, 49]), children with brain injury (e.g., articles $[28,36,50])$, children with behavior problems (e.g., articles $[27,34])$, children with hyperactivity disorder (e.g., articles $[31,51])$, children with eating disorders (e.g. articles $[33,39,40])$, children with a diagnosis of epilepsy (e.g. article [46]), infants with early adverse experiences (e.g. article [37]) and intellectually gifted adolescents (e.g. article [52]). There were articles related to relationships with parents and the incorporation of parenting styles (e.g., articles [29, 39, 44]), two related to the abuse of substances such as alcohol (e.g., articles [47, 48]). Two others who performed a construct validation with structural equations and different psychological evaluations related to self-regulation (e.g., article ([42, 51]). Finally, articles were detected that focused on the effects of an intervention that aims to develop self-regulatory capacity (e.g., articles [30, 31])

\subsection{The Potential Dimensions of Self-Regulation and its Conceptualizations}

Not all articles presented an explicit definition of selfregulation or of the theoretical constructs that support its conceptualization. In this regard, two articles were essential to guide our results because they delve into the conceptualization of self-regulation (articles [42, 51]).

One was carried out by the group of Malanchini, Engenlhardl, Grotzinger, Harden \& Tucker-Drob (2018) [42] and the other was carried out by the researchers Tiego, Bellgrove, Whittle, Pantelis and Testa (2018) [51]. The interpretation as a whole strengthened at least two theoretical currents from which self-regulation can be measured: Cognitive and Personality dimensions [51]. 
The cognitive dimension of self-regulation contemplates executive functions, which are cognitive processes that supervise, monitor and control the most basic processes related to thinking, reasoning and decision-making. Furthermore, Malanchini et al. (2018) and Tiego et al. (2018) state that inhibitory control would be a part of executive functions, which refers to the ability to control predominant responses $[42,51]$. The concept of inhibitory control was studied as a central component within the autoregulatory capacity $[25,34$, 42, 52]. Specifically, article 28 of Urben et al. (2018) studied 39 intellectually gifted adolescents. They studied the influence of emotions on inhibitory control evaluated using a Stop Signal task, with the aim of evaluating the relationship between cognitive control and emotional abilities [52]. The results showed that the main effect was obtained in the higher performance of the cognitive task of the STOP stimulus and in a shorter reaction time in the emotional responses associated with sadness in intellectually gifted adolescents, which would imply a different inhibitory capacity decrease to adolescents with typical development [52].

Malanchini et al. (2018) incorporate working memory (memory system of temporary limited capacity that maintains and stores information [54], switching (ability to change attention in the face of a different stimulus) and updating (ability to replace the previous information with the incoming one) as dimensions of self-regulation $[9,42]$.

Likewise, Tiego et al. (2018) incorporate the capacity of effortful control into self-regulation. This includes the efficiency of top-down executive attention in children and adolescents that gives them the ability to control cognition, emotion, and behavior in a goal-oriented manner [51].

A common aspect of the selected articles presenting a cognitive dimension of self-regulation is that they repeatedly mention cutting-edge research associated with temperament, development of attention and executive functions, among others $[17,55,56]$. A clear example was Tiego et al. (2018) who investigated the relationship between the behavioral measures of executive function and effortful control (e.g., BRIEF), and the relationship with performance in cognitive executive attention tasks, and problems associated with developmental psychopathology, based on different measurements. A factor analysis was performed, which reported that cognitive self-regulation processes underlie a unitary construct [51]. Likewise, it reported that executive attention as part of self-regulation significantly explained the variance in the self-regulation construct measured by behavioral measures of executive function and effortful control. Undoubtedly, the results show a strong overlap between the concepts of effortful control and executive functions, which is consistent with previous studies [4, 57].
As for self-regulation in its dimension associated with personality, Malanchini et al. (2018) [42] incorporate conceptualizations from Diamond (2013), who proposes that self-regulation allows motivation and interest to achieve one's goals [9]. This ability changes during development and is related to motivation [58]. Bridgett, Oddi, Laake, Murdock \& Bacjmann (2013) also refer to the self-regulatory capacity as a complex process that allows guiding activities aimed at objectives over time through changing circumstances [4]. Article [35] by researchers Hanson, Gillmore, Yu, Holmes, Hallowell, Barton, Beach, Galván, MacKillop, Windle, Chen, Miller, Sweet \& Brody (2019) associated low self-regulatory capacity with externalizing behavioral problems.

This personality dimension of self-regulation was measured in many of the selected articles through adult ratings of children, observing their behavior within different environments such as at home or school, incorporating more ecological measures. Likewise, in the selected articles [26, 27, $31,45]$, different observations were made of the behavior of the children. Levels of irritability, anxiety, impulsivity, among others, were evaluated in different interventions or contexts. The factorial model of personality (Big Five; Costa and McCrae, 1992) that contemplates openness, conscientiousness, extraversion, kindness, and neuroticism, are also reported within the selected articles [42].

For both dimensions of self-regulation, cognitive and personality, concepts within the articles were sought that could contribute to a better understanding of their underlying theoretical constructs. The definitions of self-regulatory capacity did not appear in all the articles. In some, the concept was explicitly defined and in others, the definition could only be deduced once the entire article had been analyzed.

In order to contribute to the comprehension of the concept of self-regulation, all of the selected articles were classified according to their level of description and deepening of the concept of self-regulation (Table 4).

\subsection{Report of the Instruments used to Measure Self- Regulation}

In this section, the numerous instruments used to measure self-regulation are organized. Only the instruments that the authors report as a measure of self-regulation were analyzed, which allowed for the verification of objectives or hypothesis linked to self-regulation. The instruments used to measure selfregulation are classified in Table $\mathbf{5}$ according to alphabetical order. In addition, the type of measurement, the potential dimension of self-regulation that the instrument targets (Cognitive / Personality) and the aspects evaluated by the instruments associated with self-regulation are described.

Table 4. Classifies the selected.

\begin{tabular}{|c|c|}
\hline Types Conceptualizations of Self-Regulation & Article \\
\hline Explicit definition & {$[14,16,23,26,28,30,33,50-53]$} \\
\hline Implicit conceptualization & {$[31,34,36,39-41,46-49]$} \\
\hline The article uses the concept without providing an explicit or implicit definition & {$[25,27,29-32]$} \\
\hline
\end{tabular}


Table 5. Summary of the principal instruments used in the article.

\begin{tabular}{|c|c|c|c|c|}
\hline Assessment Instrument & Article & $\begin{array}{l}\text { Measurement } \\
\text { Type }\end{array}$ & $\begin{array}{c}\text { Self-Regulation Dimension } \\
\text { Proposal }\end{array}$ & $\begin{array}{c}\text { Concept Associated with Self- } \\
\text { Regulation }\end{array}$ \\
\hline $\begin{array}{l}\text { Aberrant Behavior Checklist - Community } \\
(\mathrm{ABC}-\mathrm{C})\end{array}$ & {$[32]$} & $\begin{array}{c}\text { Report } \\
\text { questionnaire }\end{array}$ & $\begin{array}{l}\text { Self-regulation in the } \\
\text { personality domain }\end{array}$ & Irritability, hyperactivity \\
\hline Assessment Instrument & Article & $\begin{array}{c}\text { Measurement } \\
\text { Type }\end{array}$ & $\begin{array}{c}\text { Self-Regulation Dimension } \\
\text { Proposal }\end{array}$ & $\begin{array}{c}\text { Concept Associated with Self- } \\
\text { Regulation }\end{array}$ \\
\hline $\begin{array}{l}\text { Ages and Stages Questionnaires: Social } \\
\text { Emotional }\end{array}$ & {$[36]$} & $\begin{array}{c}\text { Report } \\
\text { questionnaire }\end{array}$ & $\begin{array}{l}\text { Self-regulation in the } \\
\text { personality domain }\end{array}$ & Emotional self-regulation \\
\hline 2-Back task (Jaeggi et al., 2010) & {$[42]$} & Task & \begin{tabular}{|c|}
$\begin{array}{c}\text { Self-regulation in the cognitive } \\
\text { domain }\end{array}$ \\
\end{tabular} & executive function/ Updating \\
\hline $\begin{array}{l}\text { Balloon Analogue Risk Task for Children } \\
\text { (BART-C) }\end{array}$ & {$[26]$} & Task & $\begin{array}{c}\begin{array}{c}\text { Self-regulation in the cognitive } \\
\text { domain }\end{array} \\
\end{array}$ & executive function/ hot cognition \\
\hline \multicolumn{5}{|l|}{ Big Five dimensions of personality (BFI) } \\
\hline (BFI) Openess & {$[42]$} & $\begin{array}{c}\text { Report } \\
\text { questionnaire }\end{array}$ & $\begin{array}{l}\text { Self-regulation in the } \\
\text { personality domain }\end{array}$ & Openess \\
\hline (BFI) Conscientiousness & {$[42]$} & $\begin{array}{c}\text { Report } \\
\text { questionnaire }\end{array}$ & $\begin{array}{l}\text { Self-regulation in the } \\
\text { personality domain }\end{array}$ & Conscientiousness \\
\hline \multicolumn{5}{|l|}{ BRIEF } \\
\hline $\begin{array}{l}\text { BRIEF-P: Global Executive Composite } \\
\text { (GEC) }\end{array}$ & {$[58]$} & $\begin{array}{c}\text { Report } \\
\text { questionnaire }\end{array}$ & $\begin{array}{c}\text { Self-regulation in the cognitive } \\
\text { domain }\end{array}$ & \\
\hline $\begin{array}{l}\text { BRIEF-P: BRI + Metacognition Index } \\
\text { (puntajes de cada una de las } 8 \text { escalas) }\end{array}$ & {$[51]$} & $\begin{array}{c}\text { Report } \\
\text { questionnaire }\end{array}$ & $\begin{array}{c}\text { Self-regulation in the cognitive } \\
\text { domain }\end{array}$ & Executive function \\
\hline $\begin{array}{l}\text { BRIEF-P: Behavior Regulation Index (BRI) } \\
\text { (Inhibit, Shift y Emotional Control) }\end{array}$ & $\begin{array}{c}{[28]} \\
{[49],[50]} \\
\end{array}$ & $\begin{array}{c}\text { Report } \\
\text { questionnaire }\end{array}$ & $\begin{array}{c}\begin{array}{c}\text { Self-regulation in the cognitive } \\
\text { domain }\end{array} \\
\end{array}$ & $\begin{array}{l}\text { Executive function / emotional self- } \\
\text { regulation-emotional control }\end{array}$ \\
\hline \multicolumn{5}{|c|}{ Cambridge Neuropsychological Test Automated (CANTAB) } \\
\hline CANTAB: Intra/extra dimensional shift & {$[47]$} & Task & $\begin{array}{c}\begin{array}{c}\text { Self-regulation in the cognitive } \\
\text { domain }\end{array} \\
\end{array}$ & $\begin{array}{c}\text { Cognitive executive function, set } \\
\text { shifting }\end{array}$ \\
\hline CANTAB: Stockings of Cambridge (SOC) & {$[47]$} & Task & $\begin{array}{c}\begin{array}{c}\text { Self-regulation in the cognitive } \\
\text { domain }\end{array} \\
\end{array}$ & $\begin{array}{c}\text { Cognitive executive function, } \\
\text { planificación }\end{array}$ \\
\hline \multicolumn{5}{|l|}{ Child Behavior Checklist (CBCL) } \\
\hline $\begin{array}{l}\text { CBCL: Subescala de delincuencia (D- } \\
\text { CBCL) }\end{array}$ & {$[35]$} & $\begin{array}{c}\text { Report } \\
\text { questionnaire }\end{array}$ & $\begin{array}{l}\text { Self-regulation in the } \\
\text { personality domain }\end{array}$ & Impulsivity, externalizing symptoms \\
\hline $\begin{array}{l}\text { Cognitive Flexibility (Baym, Corbett, } \\
\text { Wright, \& Bunge, 2008) }\end{array}$ & {$[42]$} & Task & $\begin{array}{c}\begin{array}{c}\text { Self-regulation in the cognitive } \\
\text { domain }\end{array} \\
\end{array}$ & Executive function, Switching \\
\hline $\begin{array}{l}\text { Conners' Abbreviated Teacher Rating Scale } \\
\text { (CATRS-10) }\end{array}$ & {$[27]$} & $\begin{array}{l}\text { Report } \\
\text { questionnaire }\end{array}$ & $\begin{array}{l}\text { Self-regulation in the } \\
\text { personality domain }\end{array}$ & $\begin{array}{l}\text { Behavioral self-regulation (Bowling); } \\
\text { inattention, impulsivity, hyperactivity, } \\
\text { emotional lability }\end{array}$ \\
\hline Delay Gratification Task (DGT) & {$[28]$} & Task & $\begin{array}{l}\text { Self-regulation in the } \\
\text { personality domain }\end{array}$ & Behavioral self-regulation-Impulsivity \\
\hline $\begin{array}{l}\text { Dweck Mindset Instrument (Incremental } \\
\text { inteligence) }\end{array}$ & {$[42]$} & $\begin{array}{c}\text { Report } \\
\text { questionnaire }\end{array}$ & $\begin{array}{l}\text { Self-regulation in the } \\
\text { personality domain }\end{array}$ & Incremental Intelligence \\
\hline $\begin{array}{l}\text { Early Adolescent Temperament } \\
\text { Questionnaire - Revised (Ellis \& Rothbart, } \\
\text { 2001; adapted from Capaldi \& Rothbart, } \\
\text { 1992) }\end{array}$ & {$[48],[51]$} & $\begin{array}{c}\text { Report } \\
\text { questionnaire }\end{array}$ & $\begin{array}{l}\text { Self-regulation in the } \\
\text { personality domain }\end{array}$ & $\begin{array}{l}\text { Effortful Temperament-Control (Tiego, } \\
\text { 2020) }\end{array}$ \\
\hline Emotional Regulation Checklist (ERCL) & {$[28]$} & $\begin{array}{c}\text { Report } \\
\text { questionnaire }\end{array}$ & $\begin{array}{l}\text { Self-regulation in the } \\
\text { personality domain }\end{array}$ & Emotional self-regulation \\
\hline $\begin{array}{l}\text { Grit (adapted from Duckworth \& Quinn, } \\
\text { 2009) }\end{array}$ & {$[42]$} & $\begin{array}{c}\text { Report } \\
\text { questionnaire }\end{array}$ & $\begin{array}{c}\text { Self-regulation in the } \\
\text { personality domain }\end{array}$ & Effortful persistance (grit) \\
\hline Go/No-Go "Zookepers" & {$[34]$} & Task & $\begin{array}{c}\text { Self-regulation in the cognitive } \\
\text { domain }\end{array}$ & Inhibition control \\
\hline Keeping Track (A Miyake et al., 2000) & {$[42]$} & Task & $\begin{array}{c}\begin{array}{c}\text { Self-regulation in the cognitive } \\
\text { domain }\end{array} \\
\end{array}$ & Executive function-Updating \\
\hline Local-Global (Miyake et al.,2000) & {$[42]$} & Task & $\begin{array}{c}\text { Self-regulation in the cognitive } \\
\text { domain }\end{array}$ & Executive function-Switching \\
\hline Matching Familiar Figure Test (MFFT) & {$[28]$} & Task & $\begin{array}{l}\text { Self-regulation in the } \\
\text { personality domain }\end{array}$ & Cognitive self-regulation, Impulsivity \\
\hline Mickey (Lee, Bull, \& Ho, 2013) & {$[42]$} & Task & $\begin{array}{c}\text { Self-regulation in the cognitive } \\
\text { domain }\end{array}$ & Executive function / Inhibition \\
\hline
\end{tabular}




\begin{tabular}{|c|c|c|c|c|}
\hline Monetary Choice Questionnaire & {$[53]$} & Task & $\begin{array}{c}\text { Self-regulation in the cognitive } \\
\text { domain }\end{array}$ & Delay Discounting \\
\hline $\begin{array}{l}\text { Multidimensional Achievement-relevant } \\
\text { Personality Scale (MAPS; Briley et al.,2014) }\end{array}$ & {$[42]$} & $\begin{array}{c}\text { Report } \\
\text { questionnaire }\end{array}$ & $\begin{array}{l}\text { Self-regulation in the } \\
\text { personality domain }\end{array}$ & Intellectual self-concept \\
\hline N-Back task (Jaeggi et al., 2010) & {$[42]$} & Task & $\begin{array}{c}\text { Self-regulation in the cognitive } \\
\text { domain }\end{array}$ & Executive function, Updating \\
\hline NEPSY-II Affect Recognition subtest & {$[47]$} & Task & $\begin{array}{l}\text { Self-regulation in the } \\
\text { personality domain }\end{array}$ & Socio-affective Executive Function \\
\hline NEPSY-II Inhibition subtest & {$[47]$} & Task & $\begin{array}{c}\text { Self-regulation in the cognitive } \\
\text { domain }\end{array}$ & Inhibition, Cognive Executive Function \\
\hline $\begin{array}{l}\text { Need for cognition scale (Cacioppo, Petty, } \\
\text { Feinstein, \& Jarvis, 1996) }\end{array}$ & {$[42]$} & $\begin{array}{c}\text { Report } \\
\text { questionnaire }\end{array}$ & $\begin{array}{l}\text { Self-regulation in the } \\
\text { personality domain }\end{array}$ & Personality \\
\hline $\begin{array}{l}\text { Patterns and Adaptive Leaning Scale } \\
\text { (PALS), Scale de Mastery goal orientation } \\
\text { (Revised) }\end{array}$ & {$[42]$} & $\begin{array}{c}\text { Report } \\
\text { questionnaire }\end{array}$ & $\begin{array}{l}\text { Self-regulation in the } \\
\text { personality domain }\end{array}$ & Mastery goal orientation \\
\hline $\begin{array}{l}\text { PALS, Scale de Relevance of School for } \\
\text { Future Success, Skepticism }\end{array}$ & [42] & $\begin{array}{c}\text { Report } \\
\text { questionnaire }\end{array}$ & $\begin{array}{l}\text { Self-regulation in the } \\
\text { personality domain }\end{array}$ & Educational value \\
\hline Plus-Minus (Miyake et al., 2000) & {$[42]$} & Task & $\begin{array}{c}\text { Self-regulation in the cognitive } \\
\text { domain }\end{array}$ & Executive function, Switching \\
\hline $\begin{array}{l}\text { Running Memory for Letters (Broadway \& } \\
\text { Engle, 2010) }\end{array}$ & {$[42]$} & Task & $\begin{array}{c}\text { Self-regulation in the cognitive } \\
\text { domain }\end{array}$ & Executive function-Updating \\
\hline Self-Regulation Inventory (SRI) & {$[35]$} & $\begin{array}{c}\text { Report } \\
\text { questionnaire }\end{array}$ & $\begin{array}{l}\text { Self-regulation in the } \\
\text { personality domain }\end{array}$ & Self-regulation-externalizing symptoms \\
\hline \multicolumn{5}{|l|}{ Stop Signal } \\
\hline $\begin{array}{l}\text { Auditory Stop Signal (Verbruggen, Logan, } \\
\& \text { Stevens, 2008) }\end{array}$ & {$[42]$} & Task & $\begin{array}{c}\text { Self-regulation in the cognitive } \\
\text { domain }\end{array}$ & Executive functions / Inhibition \\
\hline $\begin{array}{l}\text { Visual Stop Signal (Chevrier, Noseworthy, } \\
\text { \& Schachar, 2007) }\end{array}$ & {$[42]$} & Task & $\begin{array}{c}\text { Self-regulation in the cognitive } \\
\text { domain }\end{array}$ & Executive functions / Inhibition \\
\hline $\begin{array}{l}\text { Stop Signal adapted from Pessoa et al. } \\
\text { (2012) }\end{array}$ & {$[52]$} & Task & $\begin{array}{c}\text { Self-regulation in the cognitive } \\
\text { domain }\end{array}$ & Response inhibition \\
\hline Survey Signal & {$[40],[41]$} & Task & $\begin{array}{l}\text { Self-regulation in the } \\
\text { personality domain }\end{array}$ & Impulse control \\
\hline \multicolumn{5}{|l|}{ Stroop } \\
\hline $\begin{array}{l}\text { Animal Stroop (Wright, Waterman, Prescott, } \\
\text { \& Murdoch-Eaton, 2003) }\end{array}$ & [42] & Task & $\begin{array}{c}\text { Self-regulation in the cognitive } \\
\text { domain }\end{array}$ & Executive functions / Inhibition \\
\hline Stroop task (Golden, 1978) & [43] & Task & $\begin{array}{c}\text { Self-regulation in the cognitive } \\
\text { domain }\end{array}$ & Self-regulatory control \\
\hline \multicolumn{5}{|l|}{ Test of Everyday Attention (TEA-CH) } \\
\hline TEA-CH: Balloon Hunt & {$[28]$} & Task & $\begin{array}{c}\text { Self-regulation in the cognitive } \\
\text { domain }\end{array}$ & Cognitive Self-regulation \\
\hline TEA-CH: Hide and Seek & [28] & Task & $\begin{array}{c}\text { Self-regulation in the cognitive } \\
\text { domain }\end{array}$ & Cognitive Self-regulation \\
\hline TEA-CH: Hector cancellation & {$[28]$} & Task & $\begin{array}{c}\text { Self-regulation in the cognitive } \\
\text { domain }\end{array}$ & Cognitive Self-regulation \\
\hline TEA-CH: Hecuba Visual Search & [28] & Task & $\begin{array}{c}\text { Self-regulation in the cognitive } \\
\text { domain }\end{array}$ & Cognitive Self-regulation \\
\hline TEA-Ch: Score. Subtest & [47] & Task & $\begin{array}{c}\text { Self-regulation in the cognitive } \\
\text { domain }\end{array}$ & $\begin{array}{l}\text { Cognitive executive function, } \\
\text { auditory attention }\end{array}$ \\
\hline TEA-Ch: Sky search & [47] & Task & $\begin{array}{c}\text { Self-regulation in the cognitive } \\
\text { domain }\end{array}$ & $\begin{array}{c}\text { Cognitive executive function, visual } \\
\text { attention }\end{array}$ \\
\hline \multicolumn{5}{|c|}{ The Test of Social Cognition (Saltzman-Benaiah \& Lalonde, 2007) } \\
\hline $\begin{array}{l}\text { The Test of Social Cognition: False Beliefs } \\
\text { Subtest }\end{array}$ & {$[47]$} & Task & $\begin{array}{c}\text { Self-regulation in the cognitive } \\
\text { domain }\end{array}$ & $\begin{array}{l}\text { Socio-affective executive function, } \\
\text { social cognition }\end{array}$ \\
\hline $\begin{array}{l}\text { The Test of Social Cognition: Personalized } \\
\text { Emotions subtest }\end{array}$ & {$[47]$} & Task & $\begin{array}{c}\text { Self-regulation in the cognitive } \\
\text { domain }\end{array}$ & $\begin{array}{l}\text { Socio-affective executive function, } \\
\text { social cognition }\end{array}$ \\
\hline $\begin{array}{l}\text { The Test of Social Cognition: Personalized } \\
\text { Thoughts Subtest }\end{array}$ & {$[47]$} & Task & $\begin{array}{c}\text { Self-regulation in the cognitive } \\
\text { domain }\end{array}$ & $\begin{array}{l}\text { Socio-affective executive function, } \\
\text { social cognition }\end{array}$ \\
\hline $\begin{array}{l}\text { The Test of Social Cognition: Strategic } \\
\text { Control of Emotions }\end{array}$ & {$[47]$} & Task & $\begin{array}{c}\text { Self-regulation in the cognitive } \\
\text { domain }\end{array}$ & $\begin{array}{l}\text { Socio-affective executive function, } \\
\text { social cognition }\end{array}$ \\
\hline $\begin{array}{l}\text { The Test of Social Cognition: False Beliefs } \\
\text { Subtest }\end{array}$ & {$[47]$} & Task & $\begin{array}{c}\text { Self-regulation in the cognitive } \\
\text { domain }\end{array}$ & $\begin{array}{l}\text { Socio-affective executive function, } \\
\text { social cognition }\end{array}$ \\
\hline
\end{tabular}




\begin{tabular}{|c|c|c|c|c|}
\hline Trail Making (Salthouse, 2011) & [42] & Task & $\begin{array}{c}\text { Self-regulation in the cognitive } \\
\text { domain }\end{array}$ & Executive functions, Switching \\
\hline WM Digit Span Backward (Wechsler, 2003) & [42] & Task & $\begin{array}{c}\text { Self-regulation in the cognitive } \\
\text { domain }\end{array}$ & Executive functions / Working memory \\
\hline WM Symmetry Span (Kane et al., 2004) & [42] & Task & $\begin{array}{c}\text { Self-regulation in the cognitive } \\
\text { domain }\end{array}$ & Executive functions / Working memory \\
\hline $\begin{array}{l}\text { WM Listening Recall (Daneman \& } \\
\text { Carpenter, 1980) }\end{array}$ & [42] & Task & $\begin{array}{c}\text { Self-regulation in the cognitive } \\
\text { domain }\end{array}$ & Executive functions / Working memory \\
\hline $\begin{array}{l}\text { Zuckerman-Kuhlman-Aluja Personality } \\
\text { Questionnaire (ZKA-P), Impulsivity Scale }\end{array}$ & [42] & $\begin{array}{c}\text { Report } \\
\text { questionnaire }\end{array}$ & $\begin{array}{l}\text { Self-regulation in the } \\
\text { personality domain }\end{array}$ & Impulsiveness \\
\hline
\end{tabular}

\subsection{Main Neurobiological Findings of Self-Regulation}

This last section shows the main neurobiological correlates associated with the tasks used to evaluate self-regulation. Only 11 of the articles selected for this review presented results related to neurobiology. All reviewed articles used noninvasive techniques, widely used in neurosciences, such as functional magnetic resonance imaging (fMRI) and electroencephalography (EEG).

Regarding the use of functional magnetic resonance imaging techniques, the randomized controlled study by Hanson et al. (2019) evaluated the effect of an intervention program focused on the mitigation of stressors associated with poverty. This study considered, among others, infants with an average age of 11 years 2 months $(n=93)$. There were significant differences between the group that received the intervention compared to the control group, mainly in the area of the left dentate gyrus and in the right ventromedial prefrontal cortex (vmPFC) [35].

Another article that presented neurobiological findings was Lim et al. (2015), who used a decision-making task associated with healthy eating preferences in infants and how they incorporate the recommendations of their own mothers when choosing the type of diet $(n=25)$. They reported that vmPFC further encodes children's own preference and that an increase in the left dorsolateral prefrontal cortex (dIPFC) was associated with the children's responses when they incorporate their mother's projected choices. Also, an increase in activity of the dIPFC was shown when compared to inhibitory control-type functions when children established their own preferences about their food [39].

Also, Musarak et al. (2018) studied the relationship between parental control over children and neuronal and behavioral responses to socio-emotionally challenging situations in 27 children. Greater parental control was associated with children with lower self-esteem and lower selfregulatory capacity, when responding to a face conflict categorization task, which asked to indicate whether the faces showed fear or happiness. Greater parental control and faster but less precise behavioral responses were associated with less activation in the left anterior insula. This is complemented by article 29, where a greater activation of the anterior cingulate cortex (ACC) and the dlPFC was reported in a delay discounting task in 228 adolescents [44].

Article [40] by researchers Lopez, Chen, Huckins, Hofmann, Kelley \& Heatherton (2017) conceptualizes selfregulation based on the equilibrium theory proposed by Heatherton and Wagner (2011) [19], which supports the idea of a balance between the activity of ascending subcortical neuronal regions (from amygdala and nucleus accumbens towards cortex) and descending prefrontal neural regions (lateral prefrontal cortex towards subcortical). Failure of selfregulation occurs when the balance tips in favor of the subcortical regions. This translates into an inverse relationship between the descending cognitive control of the prefrontal cortex over the affective impulses from below - above the subcortical regions involved in the generation and reward of emotions.

As for EEG techniques, Grabell et al. (2017) studied infants with behavioral problems $(n=20)$ and control subjects $(\mathrm{n}=30)$ during a Go / No-go task adapted to evoke certain event-related potentials (ERP). They observed that there is a positivity related to the error ( $\mathrm{Pe}$ is a positivity of the signal approximately $200-400 \mathrm{~ms}$ after the onset of a commission error and the maximum amplitude of the Pe has been reported in frontal, frontocentral and parietal locations. Initially framed as a component related to conscious processing or evaluating errors after they have occurred.) and a No-go N2, which is presented as a negative deviation with Fronto-central electrode distribution that occurs in adults between 200 and $400 \mathrm{~ms}$ after the presentation of a No-go stimulus. Both ERPs identified preschoolers with high levels of disruptive behavior. Specifically, it showed that the children with better behavior presented a greater amplitude in Pe and No-go N2. Ultimately, Grabell et al. (2017) report that the increase in Pe is associated with a better processing of the negative effect after an error and a greater response of the autonomic nervous system to errors, as well as the increase in the amplitude of No-go N2, which would reflect a greater cognitive control required to inhibit a response or a greater level of conflict between competitive responses, that is, execution versus inhibition [34].

Finally, the reviewed articles that present neurobiological findings suggest that the generalizability of their results needs to be evaluated with caution. In addition, most of the studies emphasize limitations associated with the sample size, which affects the robustness of the findings.

\section{DISCUSSION}

This systematic review aimed to evaluate the literature on self-regulatory capacity in the last five years. In these years, an increase in the publications of the selected articles was observed during 2018. More than half of the articles were from the United States, which shows the need to study these topics in other countries.

Some researchers suggest that the limits of self-regulatory capacity as an object of study are controversial [42, 51, 59]. 
Proof of this is the high number of articles excluded by title and abstract. The number of articles selected was further reduced when age group criteria were incorporated, including only samples ranging from early childhood to late adolescence. Most of the selected articles only addressed a subsection within this age range, so it was not possible to fully observe the full age range within one article.

A PICOS analysis was performed regarding the participants, the type of sample associated with the clinical diagnosis of typical or atypical development, the interventions, comparisons of the samples, the results related to the dimension and the concept of self-regulation, and the type of study design reported. Only those articles that explicitly described the population with a clinical diagnosis were categorized as having atypical development.

All the articles that did not present a clinical diagnosis were incorporated as being part of the typical development spectrum. However, this reveals the need to characterize and delve into how self-regulatory capacity matures, following the foundations proposed by Rothbart and Posner, among others $[17,60]$.

Only seven articles carried out intervention with a small sample and with short intervention periods, which raises a problem in the effects of the evaluations of the interventions. This is in addition to the fact that no findings were found on the prevention or promotion of self-regulation as a key component of human behavior. The decrease in self-regulation is reported within atypical development and its enhancement could influence the mental health of children, which would be important for public health policy.

This systematic review of the literature sought to contribute to the evaluation of the self-regulatory capacity and identify possible latent dimensions linked to this process. Traditionally, the concept is reported in its cognitive dimension with neurobiological correlates. Related to this dimension, different cognitive proposals appear from widely cited researchers such as: Barkley [61]; Rothbart [17, 60, 62]; Heatherton [19]; Nigg [7]. In the personality dimension, some commonly cited authors are Diamond [9]; Bridgett [4]; Digman [63], among others.

Several tables were incorporated that propose a way to integrate the information and improve the learning of readers interested in understanding self-regulation. The reported instruments were only linked to self-regulation. Also, the type of measurement of the instruments was described, which were either questionnaires or task-based tests. Generally, the questionnaires were applied in natural environments by the parents of the infants.

Perhaps a possible analysis that underlies both dimensions of self-regulation would be the capacity for self-control, understood as a process in which the subject tries to suppress unwanted preponderant tendencies or impulses in a conscious and effortful way. This means that self-control is a broader concept than executive functions because it includes control processes, and processes and components such as: preventive strategies, desire, conflict, will, internal restrictions, initiation and metacognitive strategies, etc [5]. Self-control is considered a process in which people have the resources to make their actions conscious, so it is usually linked to willpower or control of one's will $[33,40]$. Specifically, self-control would be the ability to cancel or modify internal responses, behavioral tendencies (impulses) and voluntarily refrain from acting on them [27]. Therefore, it demands a successful control of impulses [5]. One way to delve into the process of self-control of impulsive behaviors is through the capacity of inhibition. Researchers describe that there are approaches associated with inhibition processes that break down the construct into a set of mechanisms that have functional properties and characteristics, supporting three types of inhibition [8]. The first type would be perceptual inhibition, which would be responsible for suppressing irrelevant stimuli from the environment; second would be cognitive inhibition, which is involved in the reduction of representations that are intrusive and irrelevant for the achievement of current goals; third would be behavioral inhibition, which would be responsible for suppressing preponderant and inappropriate behavioral responses or impulses in the context of the activity that is in progress [9, 25, 52]. However, there are various theoretical positions that analyze inhibitory control, either as a central element or as part of executive functioning $[7,11]$.

Only the instruments that were reported as a measure of self-regulation within the selected studies were described in this review. This is because most of the articles presented instruments for other study objectives as well, which the researchers did not necessarily report as a measure of selfregulation. Moreover, the instrument types were described and classified as either a questionnaire or a task-based test, which could serve as a guide for other researchers in the process of deciding which instrument should be selected to measure selfregulatory capacity. Generally, the questionnaires were based on the observations by the parents of the behaviors of the children, which allowed more ecological measures of selfregulation. The ideal scenario is an integrated evaluation that includes instruments with more ecological characteristics and different observers (e.g., teachers, parents and self-report measures), as well as tests in more structured contexts, with the aim of analyzing the capacity of translation and generalization of learning in different environments [30, 39, 50].

This review allowed us to link theoretical models of selfregulation with the tasks used to measure the construct. These frame self-regulation as a multi-component processing that involves a complex neurobiological capacity closely related to prefrontal regions of the brain, typical of the anterior attention network (e.g., dorsal anterior cingulate, dentate gyrus, dorsolateral prefrontal cortex, and ventromedial prefrontal cortex) $[33,35,39]$. These regions were shown to play an important role in conflict resolution. The neuroscience techniques for the evaluation of neurobiological correlates were mainly functional magnetic resonance imaging (fMRI), which reports high spatial resolution, and electroencephalography (EEG), a technique with high temporal precision. Only two of the selected articles used electroencephalographic measures, in which a negativity at $200 \mathrm{~ms}$ (N2) was a marker in inhibitory control tasks [34, 37]. Some of the selected articles argue that self-regulatory capacity is a complex process that begins in childhood. This is complemented by the fact that Elias \& Berk (2002) state that self-regulation is fostered in spontaneous play and serves as the basis for designing effective clinical intervention efforts. From this, it can be considered as a mental process that is highly sensitive to the environment since it includes adaptation and 
learning processes of the subject, and it is possible to approach it in a multidimensional way [64]. Barkley (1997) suggests within the self-regulation model that the ideal intervention for children with a diagnosis of attention deficit/hyperactivity disorder (ADHD) would be one based on play within natural environments [17]. This is consistent with research that argues that therapy in self-regulatory capacity in children with neurodevelopmental difficulties such as the fetal alcohol syndrome spectrum presented behavioral changes and an increase of the brain tissue of the frontal region analyzed with voxel-based morphometry [65].

As for the limitations of this review, one of them is that only one database (PUBMED) was incorporated, suggesting that the search should be broadened to other databases with the aim of collecting a greater number of articles. Likewise, it is important to extend the age range included in future reviews in order to understand not only the stages of childhood and adolescence but also the entire life cycle of the human being in order to obtain a broader view of how self-regulatory capacity evolves. Furthermore, incorporating genetic studies by expanding the search words would also contribute to the idea of self-regulation as a capacity that is sensible to the environment.

Finally, we propose to advance towards incorporating statistical measures that integrate the selected articles. This could be projected as a meta-analysis with the aim of improving the empirical evidence on the reported findings. Another future direction of the study of self-regulatory capacity would be to organize its related concepts into clusters, in order to identify other potential dimensions of self-regulation, contributing to a more comprehensive and integrative view of self-regulatory capacity in the different areas of human development.

\section{CONCLUSION}

In conclusion, this article presented the realization of a systematic review of the literature on the evaluation of selfregulation capacity with the aim of contributing to the conceptualization of this construct. The review identified two possible dimensions that are associated with this concept, one in the cognitive domain and another in the personality domain. Also, the instruments that contribute to the measurement of this capacity were identified. In addition, neurobiological correlates mainly associated with tasks used to measure self-regulation were reported, showing activation of the anterior cingulate cortex, dorsolateral prefrontal and ventromedial prefrontal cortex. Finally, this review contributes to the understanding of self-regulatory capacity as a theoretical construct that serves as a sensitive marker of evaluation and intervention of child and adolescent development, and that its increased capacity improves adaptive behavior in the face of the demands of the environment.

\section{AUTHORS' CONTRIBUTION}

For research articles with several authors, a short paragraph specifying their individual contributions must be provided. The following statements should be used "Conceptualization, J.L.; methodology, J.L and F.M.; formal analysis, J.L and F.M.; writing - original draft preparation, J.L.; writing—review and editing, E.A., L.K.; visualization, J.L and F.M.; project administration, J.L. All authors have read and agreed to the published version of the manuscript

\section{LIST OF ABBREVIATIONS}

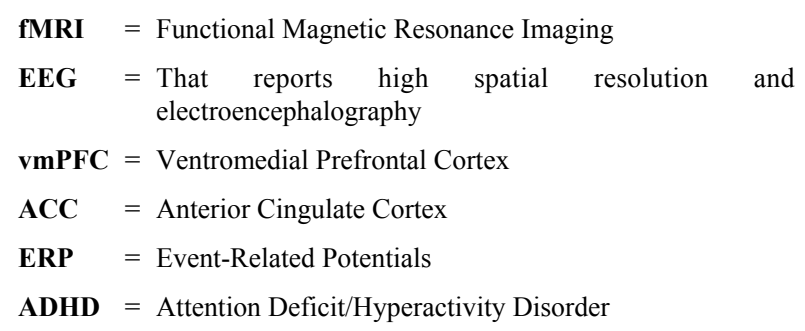

\section{CONSENT FOR PUBLICATION}

Not applicable.

\section{REGISTRATION OF SYSTEMATIC REVIEWS}

The protocol can be found on http://neurocics.udd.cl/data/Larrain-Valenzuela_et_al_2021_Pr otocolo_registro.pdf. The review was not registered.

\section{AVAILABILITY OF DATA AND MATERIALS}

The data supporting findings of this study is available at zenodo repository: https://doi.org/10.5281/zenodo.5643273.

\section{FUNDING}

This research was funded by CONICYT doctoral scholarship, grant number 21181127 to JL and post-doctoral 3190914 to LK. Both from the National Agency of Investigation and Development [Agencia Nacional de Investigación y Desarrollo], Chilean State. https://www.anid.cl/conoce-anid/.

\section{CONFLICT OF INTEREST}

The funders had no role in the design of the study, in the collection, analyses, or interpretation of data, in the writing of the manuscript, or in the decision to publish the results.

\section{ACKNOWLEDGEMENTS}

Three institutions allowed for the realization of this article. i. The Psychology PhD Program at Universidad Diego Portales. ii. The Research Center for Social Complexity, Universidad del Desarrollo, Santiago, Chile. iii. Doctoral scholarship CONICYT No 21181127.

\section{SUPPLEMENTARY MATERIAL}

PRISMA checklist is available as supplementary material on the publisher's website along with the published article.

\section{REFERENCES}

[1] Posner MI, Rothbart MK. Attention, self-regulation and consciousness. Philos Trans R Soc Lond B Biol Sci 1998; 353(1377): 1915-27.

[http://dx.doi.org/10.1098/rstb.1998.0344] [PMID: 9854264]

[2] Baumeister RF, Heatherton TF. Self-Regulation Failure: An Overview. Psychol Inq 1996; 7(1): 1-15.

[http://dx.doi.org/10.1207/s15327965pli0701_1]

[3] Aldrete-Cortez V, Carrillo-Mora P, Mansilla-Olivares A, Schnaas L, 
Ancona FE. De la regulación emocional y cognitiva a la autorregulación en el primer año de vida. Anu Psicol 2014; 44(2): 199-212.

[4] Bridgett DJ, Oddi KB, Laake LM, Murdock KW, Bachmann MN. Integrating and differentiating aspects of self-regulation: Effortful control, executive functioning, and links to negative affectivity. Emotion 2013; 13(1): 47-63.

[http://dx.doi.org/10.1037/a0029536] [PMID: 22906086]

[5] Canet-Juric L, Inotrozzi I, Andrés ML, Stelzer F. La contribución de las Funciones Ejecutivas a la Autorregulación. Cuad Neuropsicol Panam J Neuropsychol 2016; 10(2): 106-28.

[6] Ozonoff S, Dawson G, McPartland J. A Parent's Guide to Asperger Syndrome ans high-Funtioning Autism: How to Meet the Challenges and Help Your Child Thrive. New York 2002.

[7] Nigg JT. Annual Research Review: On the relations among selfregulation, self-control, executive functioning, effortful control, cognitive control, impulsivity, risk-taking, and inhibition for developmental psychopathology. J Child Psychol Psychiatry 2017; 58(4): 361-83

[http://dx.doi.org/10.1111/jcpp.12675] [PMID: 28035675]

[8] Richard's M, Vernucci S, Zamora E, Canet L, Introzzi I, Guardia J. Contribuciones Empíricas para la validez de grupos contrastados de la batería. Interdisciplinaria 2017; 34: 173-92.

[9] Diamond A. Executive Functions. Annu Rev Psychol 2013; 64(1): 135-68.

[http://dx.doi.org/10.1146/annurev-psych-113011-143750] [PMID: 23020641]

[10] Posner MI, Rothbart MK. Toward a physical basis of attention and self-regulation. Phys Life Rev 2009; 6(2): 103-20. [http://dx.doi.org/10.1016/j.plrev.2009.02.001] [PMID: 20161073]

[11] Bridgett DJ, Burt NM, Edwards ES, Deater-Deckard K. Intergenerational transmission of self-regulation: A multidisciplinary review and integrative conceptual framework. Psychol Bull 2015; 141(3): 602-54.

[http://dx.doi.org/10.1037/a0038662] [PMID: 25938878]

[12] Montroy JJ, Bowles RP, Skibbe LE, McClelland MM, Morrison FJ. The development of self-regulation across early childhood. Dev Psychol 2016; 52(11): 1744-62.

[http://dx.doi.org/10.1037/dev0000159] [PMID: 27709999]

[13] Bridgett DJ, Burt NM, Edwards ES, Deater-Deckard K. Intergenerational transmission of self-regulation: A multidisciplinary review and integrative conceptual framework. Psychol Bull 2015; 141(3): $602-54$

[http://dx.doi.org/10.1037/a0038662] [PMID: 25938878]

[14] Chein JM, Moore AB, Conway ARA. Domain-general mechanisms of complex working memory span. Neuroimage 2011; 54(1): 550-9.

[http://dx.doi.org/10.1016/j.neuroimage.2010.07.067] [PMID: 20691275]

[15] Petersen SE, Posner MI. The attention system of the human brain: 20 years after. Annu Rev Neurosci 2012; 35(1): 73-89. [http://dx.doi.org/10.1146/annurev-neuro-062111-150525] [PMID: 22524787]

[16] Barkley RA. Behavioral inhibition, sustained attention, and executive functions: Constructing a unifying theory of ADHD. Psychol Bull 1997; 121(1): 65-94.

[http://dx.doi.org/10.1037/0033-2909.121.1.65] [PMID: 9000892]

[17] Rothbart MK, Derryberry D, Posner MI. A psychobiological approach to the development of temperament.Temperament: Individual differences at the interface of biology and behavior. 1994; pp. 83-116. [http://dx.doi.org/10.1037/10149-003]

[18] Strauman TJ. Self-regulation and psychopathology: Toward an integrative translational research paradigm. Annu Rev Clin Psychol 2017; 13(1): 497-523.

[http://dx.doi.org/10.1146/annurev-clinpsy-032816-045012] [PMID: 28375727]

[19] Heatherton TF, Wagner D. Cognitive neuroscience of self-regulation failure. Cent Afr J Med 2012; 2(1): 22-5.

[20] Carrizo D, Moller C. Estructuras metodológicas de revisiones sistemáticas de literatura en Ingeniería de Software: Un estudio de mapeo sistemático. Ingeniare Rev Chil Ing 2018; 26: 45-54. [http://dx.doi.org/10.4067/S0718-33052018000500045]

[21] Urrútia G, Bonfill X. [PRISMA declaration: A proposal to improve the publication of systematic reviews and meta-analyses]. Med Clin (Barc) 2010; 135(11): 507-11. [PMID: 20206945]

[22] PRISMA Trasparent Reporting of systmatic review and meta-analyses. 2021.
[23] Guirao Goris SJA. Utilidad y tipos de revisión de literatura. Rev Enferm La Fe 2015; 9(2)

[http://dx.doi.org/10.4321/S1988-348X2015000200002]

[24] Güemes-Hidalgo M, Ceñal González-Fierro M, Hidalgo Vicario M. Pubertad y adolescencia. Adolescere. Rev. Form. Contin. la Soc. Española Med la Adolesc 2017; 5(1): 7-22.

[25] Anokhin AP, Golosheykin S, Grant JD, Heath AC, Heath AC. Heritability of brain activity related to response inhibition: A longitudinal genetic study in adolescent twins. Int J Psychophysiol 2017; 115: 112-24.

[http://dx.doi.org/10.1016/j.ijpsycho.2017.03.002] [PMID: 28300615]

[26] Bell MD, Imal AE, Pittman B, et al. The development of adaptive risk taking and the role of executive functions in a large sample of schoolage boys and girls. Trends Neurosci Educ 2019; 17: 100120

[http://dx.doi.org/10.1016/j.tine.2019.100120] [PMID: 31685124]

[27] Bowling A, Slavet J, Miller DP, Haneuse S, Beardslee W, Davison K. Cybercycling effects on classroom behavior in children with behavioral health disorders: An RCT. Pediatrics 2017; 139(2): e20161985.

[http://dx.doi.org/10.1542/peds.2016-1985] [PMID: 28069663]

[28] Chavez Arana C, Catroppa C, Yáñez-Téllez G, et al. A parenting program to reduce disruptive behavior in hispanic children with acquired brain injury: A randomized controlled trial conducted in mexico. Dev Neurorehabil 2020; 23(4): 218-30.

[http://dx.doi.org/10.1080/17518423.2019.1645224] 31345088]

[29] Densing K, Konstantinidis H, Seiler M. Effect of stress level on different forms of self-touch in pre- and postadolescent girls. J Mot Behav 2018; 50(5): 475-85.

[http://dx.doi.org/10.1080/00222895.2017.1367640]

[PMID: 28937951]

[30] Edgington L, Hill V, Pellicano E. The design and implementation of a CBT-based intervention for sensory processing difficulties in adolescents on the autism spectrum. Res Dev Disabil 2016; 59: 221-33.

[http://dx.doi.org/10.1016/j.ridd.2016.09.004] [PMID: 27639063]

[31] Fosco WD, Sarver DE, Kofler MJ, Aduen PA. Parent and child neurocognitive functioning predict response to behavioral parent training for youth with ADHD. Atten Defic Hyperact Disord 2018; 10(4): 285-95.

[http://dx.doi.org/10.1007/s12402-018-0259-8] [PMID: 30051256]

[32] Gabriels RL, Pan Z, Dechant B, Agnew JA, Brim N, Mesibov G. Randomized controlled trial of therapeutic horseback riding in children and adolescents with autism spectrum disorder. J Am Acad Child Adolesc Psychiatry 2015; 54(7): 541-9.

[http://dx.doi.org/10.1016/j.jaac.2015.04.007] [PMID: 26088658]

[33] Goldschmidt AB, Dickstein DP, MacNamara AE, et al. A pilot study of neural correlates of loss of control eating in children with overweight/obesity: Probing intermittent access to food as a means of eliciting disinhibited eating. J Pediatr Psychol 2018; 43(8): 846-55. [http://dx.doi.org/10.1093/jpepsy/jsy009] [PMID: 29462339]

[34] Grabell AS, Olson SL, Tardif T, Thompson MC, Gehring WJ. Comparing self-regulation-associated event related potentials in preschool children with and without high levels of disruptive behavior. J Abnorm Child Psychol 2017; 45(6): 1119-32.

[http://dx.doi.org/10.1007/s10802-016-0228-7] [PMID: 27891556]

[35] Hanson JL, Gillmore AD, Yu T, et al. A family focused intervention influences hippocampal-prefrontal connectivity through gains in selfregulation. Child Dev 2019; 90(4): 1389-401.

[http://dx.doi.org/10.1111/cdev.13154] [PMID: 30295319]

[36] Kaldoja ML, Kolk A. Does gender matter? Differences in socialemotional behavior among infants and toddlers before and after mild traumatic brain injury: A preliminary study. J Child Neurol 2015; 30(7): 860-7.

[http://dx.doi.org/10.1177/0883073814544705] [PMID: 25143483]

[37] Lackner CL, Santesso DL, Dywan J, O'Leary DD, Wade TJ, Segalowitz SJ. Adverse childhood experiences are associated with self-regulation and the magnitude of the error-related negativity difference. Biol Psychol 2018; 132: 244-51.

[http://dx.doi.org/10.1016/j.biopsycho.2018.01.006]

[PMID: 29309827]

[38] Lakes KD, Neville R, Vazou S, et al. Beyond broadway: Analysis of qualitative characteristics of and individual responses to creatively able, a music and movement intervention for children with autism. Int J Environ Res Public Health 2019; 16(8): 1377.

[http://dx.doi.org/10.3390/ijerph16081377] [PMID: 30999560]

[39] Lim SL, Cherry JBC, Davis AM, et al. The child brain computes and 
utilizes internalized maternal choices. Nat Commun 2016; 7(1): 11700 . [http://dx.doi.org/10.1038/ncomms11700]

[40] Lopez RB, Chen PHA, Huckins JF, Hofmann W, Kelley WM, Heatherton TF. A balance of activity in brain control and reward systems predicts self-regulatory outcomes. Soc Cogn Affect Neurosci 2017; 12(5): 832-8.

[http://dx.doi.org/10.1093/scan/nsx004] [PMID: 28158874]

[41] Lopez RB, Milyavskaya M, Hofmann W, Heatherton TF. Motivational and neural correlates of self-control of eating: A combined neuroimaging and experience sampling study in dieting female college students. Appetite 2016; 103: 192-9.

[http://dx.doi.org/10.1016/j.appet.2016.03.027] [PMID: 27058281]

[42] Malanchini M, Engelhardt LE, Grotzinger AD, Harden KP, TuckerDrob EM. "Same but different": Associations between multiple aspects of self-regulation, cognition, and academic abilities. J Pers Soc Psychol 2019; 117(6): 1164-88.

[http://dx.doi.org/10.1037/pspp0000224] [PMID: 30550329]

[43] Marsh R, Stefan M, Bansal R, Hao X, Walsh BT, Peterson BS. Anatomical characteristics of the cerebral surface in bulimia nervosa. Biol Psychiatry 2015; 77(7): 616-23.

[http://dx.doi.org/10.1016/j.biopsych.2013.07.017] [PMID: 23978404]

[44] Marusak HA, Thomason ME, Sala-Hamrick K, Crespo L, Rabinak CA. What's parenting got to do with it: Emotional autonomy and brain and behavioral responses to emotional conflict in children and adolescents. Dev Sci 2018; 21(4)e12605

[http://dx.doi.org/10.1111/desc.12605] [PMID: 28913886]

[45] Miller AL, Seifer R, Crossin R, Lebourgeois MK. Toddler's selfregulation strategies in a challenge context are nap-dependent. J Sleep Res 2015; 24(3): 279-87.

[http://dx.doi.org/10.1111/jsr.12260] [PMID: 25394169]

[46] Modi AC, Vannest J, Combs A, Turnier L, Wade SL. Pattern of executive functioning in adolescents with epilepsy: A multimethod measurement approach. Epilepsy Behav 2018; 80: 5-10. [http://dx.doi.org/10.1016/j.yebeh.2017.12.021] [PMID: 29396361]

[47] Nash K, Stevens S, Greenbaum R, Weiner J, Koren G, Rovet J. Improving executive functioning in children with fetal alcohol spectrum disorders. Child Neuropsychol 2015; 21(2): 191-209. [http://dx.doi.org/10.1080/09297049.2014.889110] [PMID: 25010354]

[48] O'connor RM, Colder CR. The prospective joint effects of selfregulation and impulsive processes on early adolescence alcohol use. $\mathrm{J}$ Stud Alcohol Drugs 2015; 76(6): 884-94.

[http://dx.doi.org/10.15288/jsad.2015.76.884] [PMID: 26562596]

[49] Rohr CS, Kamal S, Bray S. Building functional connectivity neuromarkers of behavioral self-regulation across children with and without Autism Spectrum Disorder. Dev Cogn Neurosci 2020; 41100747

[http://dx.doi.org/10.1016/j.den.2019.100747] [PMID: 31826838]

[50] Ryan NP, Reyes J, Crossley L, Beauchamp MH, Catroppa C, Anderson VA. Unraveling the association between pediatric traumatic brain injury and social dysfunction: The mediating role of selfregulation. J Neurotrauma 2019; 36(20): 2895-903.

[http://dx.doi.org/10.1089/neu.2018.6308] [PMID: 31038001]

[51] Tiego J, Bellgrove MA, Whittle S, Pantelis C, Testa R. Common mechanisms of executive attention underlie executive function and effortful control in children. Dev Sci 2020; 23(3): e12918. [http://dx.doi.org/10.1111/desc.12918] [PMID: 31680377]
[52] Urben S, Camos V, Habersaat S, Stéphan P. Faces presenting sadness enhance self-control abilities in gifted adolescents. Br J Dev Psychol 2018; 36(3): 514-20.

[http://dx.doi.org/10.1111/bjdp.12241] [PMID: 29473180]

53] Wang S, Zhou M, Chen T, Yang X, Chen G, Gong Q. Delay discounting is associated with the fractional amplitude of lowfrequency fluctuations and resting-state functional connectivity in late adolescence. Sci Rep 2017; 7(1): 10276.

[http://dx.doi.org/10.1038/s41598-017-11109-z] [PMID: 28860514]

[54] Baddeley A. Working memory: Looking back and looking forward. Nat Rev Neurosci 2003; 4(10): 829-39.

[http://dx.doi.org/10.1038/nrn1201] [PMID: 14523382]

[55] Rothbart MK. Temperament, development, and personality. Curr Dir Psychol Sci 2007; 16(4): 207-12.

[http://dx.doi.org/10.1111/j.1467-8721.2007.00505.x]

[56] Rothbart MK, Sheese BE, Rueda MR, Posner MI. Developing mechanisms of self-regulation in early life. Emot Rev 2011; 3(2): 207-13.

[http://dx.doi.org/10.1177/1754073910387943] [PMID: 21892360]

[57] Baddeley A. The central executive: A concept and some misconceptions. J Int Neuropsychol Soc 1998; 4(5): 523-6. [http://dx.doi.org/10.1017/S135561779800513X] [PMID: 9745242]

[58] Mason TB, Do B, Dunton G. Interactions of approach motivation and self-regulation in relation to obesity in children. Eat Weight Disord 2021; 26(1): 85-92.

[http://dx.doi.org/10.1007/s40519-019-00817-2] [PMID: 31784947]

[59] Nigg JT. On inhibition/disinhibition in developmental psychopathology: Views from cognitive and personality psychology and a working inhibition taxonomy. Psychol Bull 2000; 126(2): 220-46.

[http://dx.doi.org/10.1037/0033-2909.126.2.220] [PMID: 10748641]

[60] Rueda MR, Rothbart MK, McCandliss BD, Saccomanno L, Posner MI. From The Cover: Training, maturation, and genetic influences on the development of executive attention. Proc Natl Acad Sci USA 2005; 102(41): 14931-6.

[http://dx.doi.org/10.1073/pnas.0506897102] [PMID: 16192352]

[61] Barkley RA. Attention-deficit/hyperactivity disorder, self-regulation, and time: Toward a more comprehensive theory. J Dev Behav Pediatr 1997; 18(4): 271-9.

[http://dx.doi.org/10.1097/00004703-199708000-00009] [PMID: 9276836]

[62] Sheese BE, Rothbart MK, Posner MI, White LK, Fraundorf SH. Executive attention and self-regulation in infancy. Infant Behav Dev 2008; 31(3): 501-10.

[http://dx.doi.org/10.1016/j.infbeh.2008.02.001] [PMID: 18406466]

[63] Digman JM. Personality structure: Emergence of the five-factor model. Annu Rev Psychol 1990; 41(1): 417-40.

[http://dx.doi.org/10.1146/annurev.ps.41.020190.002221]

[64] Elias CL, Berk LE. Self-regulation in young children: Is there a role for sociodramatic play? Early Child Res Q 2002; 17(2): 216-38. [http://dx.doi.org/10.1016/S0885-2006(02)00146-1]

[65] Soh DW, Skocic J, Nash K, Stevens S, Turner GR, Rovet J. Selfregulation therapy increases frontal gray matter in children with fetal alcohol spectrum disorder: Evaluation by voxel-based morphometry. Front Hum Neurosci 2015; 9: 108. [http://dx.doi.org/10.3389/fnhum.2015.00108] [PMID: 25788884]

\section{C) 2022 Larraín-Valenzuela et al.}

This is an open access article distributed under the terms of the Creative Commons Attribution 4.0 International Public License (CC-BY 4.0), a copy of which is available at: https://creativecommons.org/licenses/by/4.0/legalcode. This license permits unrestricted use, distribution, and reproduction in any medium, provided the original author and source are credited. 